\title{
Complex Control of Striatal Neurotransmission by Nicotinic Acetylcholine Receptors via Excitatory Inputs onto Medium Spiny Neurons
}

\author{
Valentina Licheri, ${ }^{1} \oplus^{\circledR}$ Oona Lagström, ${ }^{1}$ Amir Lotfi, ${ }^{1}$ @Mary H. Patton, ${ }^{2}$ Holger Wigström, ${ }^{3}$ Brian Mathur, ${ }^{2}$ \\ and $\oplus_{\text {Louise Adermark }}^{1}$ \\ ${ }^{1}$ Addiction Biology Unit, Department of Psychiatry and Neurochemistry, Institute of Neuroscience and Physiology, Sahlgrenska Academy at the University \\ of Gothenburg, 40530 Gothenburg, Sweden, ${ }^{2}$ University of Maryland School of Medicine, 21201, Baltimore, Maryland, and ${ }^{3}$ Department of Medical \\ Biophysics, Sahlgrenska Academy at the University of Gothenburg, 40530 Gothenburg, Sweden
}

The prevalence of nicotine dependence is higher than that for any other substance abuse disorder; still, the underlying mechanisms are not fully established. To this end, we studied acute effects by nicotine on neurotransmission in the dorsolateral striatum, a key brain region with respect to the formation of habits. Electrophysiological recordings in acutely isolated brain slices from rodent showed that nicotine ( $10 \mathrm{~nm}$ to $10 \mu \mathrm{M}$ ) produced an LTD of evoked field potentials. Current-clamp recordings revealed no significant effect by nicotine on membrane voltage or action potential frequency, indicating that the effect by nicotine is primarily synaptic. Nicotine did not modulate sIPSCs, or the connectivity between fast-spiking interneurons and medium spiny neurons, as assessed by whole-cell recordings combined with optogenetics. However, the frequency of sEPSCs was significantly depressed by nicotine. The effect by nicotine was mimicked by agonists targeting $\alpha 7$ - or $\alpha 4$-containing nAChRs and blocked in slices pretreated with a mixture of antagonists targeting these receptor subtypes. Nicotine-induced LTD was furthermore inhibited by dopamine D2 receptor antagonist and occluded by D2 receptor agonist. In addition, modulation of cholinergic neurotransmission suppressed the responding to nicotine, which might reflect upon the postulated role for nAChRs as a presynaptic filter to differentially govern dopamine release depending on neuronal activity. Nicotine-induced suppression of excitatory inputs onto medium spiny neurons may promote nicotine-induced locomotor stimulation and putatively initiate neuroadaptations that could contribute to the transition toward compulsive drug taking.

Key words: addiction; basal ganglia; dorsolateral striatum; dopamine; electrophysiology; nAChR

Significance Statement

To decrease smoking, prevalence factors that may contribute to the development of nicotine addiction need to be identified. The data presented here show that nicotine suppresses striatal neurotransmission by selectively reducing the frequency of excitatory inputs to medium spiny neurons (MSNs) while rendering excitability, inhibitory neurotransmission, and fast-spiking interneuron-MSN connectivity unaltered. In addition, we show that the effect displayed by nicotine outlasts the presence of the drug, which could be fundamental for the addictive properties of nicotine. Considering the inhibitory tone displayed by MSNs on dopaminergic cell bodies and local terminals, nicotine-induced long-lasting depression of striatal output could play a role in behavioral transformations associated with nicotine use, and putatively elicit neuroadaptations underlying compulsive drug-seeking habits.

\section{Introduction}

Tobacco use is a leading preventable cause of death worldwide, yet $\sim 95 \%$ of those who try to quit relapse (Kandel et al., 1997). To

Received Jan. 11, 2018; revised April 6, 2018; accepted May 10, 2018.

Author contributions:V.L., O.L.,A.L., M.H.P., H.W., B.M., and L.A. edited the paper; L.A. wrote the first draft of the paper; L.A. designed research; V.L., O.L., A.L., M.H.P., B.M., and L.A. performed research; H.W. contributed unpublished reagents/analytic tools; V.L., O.L., A.L., M.H.P., B.M., and L.A. analyzed data; L.A. wrote the paper.

This work was supported by Stiftelsen Psykiatriska Forskningsfonden, the Swedish Brain Foundation, the Swedish Medical Research Council (Diary numbers 2014-3888, 2014-3887, 2015-02894), Åke Wibergs stiftelse, Bror further decrease smoking prevalence, it is thus imperative to identify factors that may contribute to the development of nicotine addiction. Even though the reinforcing properties of nicotine
Gadelius Minnesfond, Wilhelm och Martina Lundgrens vetenskapsfond, The Royal Society for Arts and Sciences in Gothenburg, Systrarna Greta Johansson och Brita Anderssons Minnesfond, Thurings stiftelse, and Åhlén-stiftelsen. The authors declare no competing financial interests.

Correspondence should be addressed to Dr. Louise Adermark, Addiction Biology Unit, Institute of Neuroscience and Physiology, University of Gothenburg, Box 410, 40530 Gothenburg, Sweden. E-mail: louise.adermark@gu.se. DOI:10.1523/JNEUROSCI.0071-18.2018

Copyright $\odot 2018$ the authors $\quad 0270-6474 / 18 / 386597-11 \$ 15.00 / 0$ 
primarily have been attributed to the mesolimbic dopamine system (Singer et al., 1982; Grenhoff et al., 1986; Benwell and Balfour, 1992; Corrigall, 1999; Di Chiara, 2000), later research has put forward dorsal striatum as a key mediator of several rewardrelated behaviors, including locomotor sensitization (Bamford et al., 2008), cue-dependent drug-seeking (Quintana et al., 2012), and compulsive drug-seeking habits (Yin et al., 2004; Vanderschuren et al., 2005; Everitt and Robbins, 2016). Dorsal striatum has especially been implicated in later stages of addiction, where there appears to be a neuroanatomical progression from ventral striatal to dorsal striatal control over drug-seeking behavior (Gerdeman et al., 2003; Volkow et al., 2006; Yin et al., 2008). Understanding the effects displayed by nicotine on dorsal striatal circuits is thus important for defining signaling pathways recruited during acute and protracted drug exposure.

The majority of neurons in the striatum are GABAergic medium spiny neurons (MSNs), which are activated in relation to movements triggered by both memory-encoded and environmental cues (Hikosaka et al., 1989). Because of the dense innervation of glutamatergic afferents from cortex and thalamus, the majority of synapses are excitatory, but striatal output is highly regulated by intrinsic inputs from GABAergic and cholinergic interneurons, and astrocytes (Zhou et al., 2002; Tepper et al., 2004; Adermark and Lovinger, 2008; Witten et al., 2010; Adermark et al., 2011a; Xu et al., 2015). nAChRs are not expressed on MSNs but widely distributed on striatal interneurons and dopaminergic and glutamatergic terminals, thereby modulating striatal output in a complex manner (Marshall et al., 1997; Kaiser and Wonnacott, 2000; Faust et al., 2016; Howe et al., 2016; Siciliano et al., 2017). Especially, nAChR activation has been reported to trigger GABAergic interneurons (English et al., 2011; Luo et al., 2013), which could indirectly alter dopaminergic firing and striatal output (Koós et al., 2004; Adermark et al., 2011a; Clarke and Adermark, 2015; Silberberg and Bolam, 2015). In addition, the effect displayed by nicotine appears to depend on baseline firing frequency (Koós and Tepper, 2002; Goutier et al., 2016). Indeed, reduced activation of $\mathrm{nAChRs}$ has been postulated to enhance dopamine bursts at high frequencies while depressing dopamine release at lower frequencies, suggesting that nAChRs may work as a presynaptic filter to differentially govern dopamine release depending on neuronal activity (Rice and Cragg, 2004). To identify acute effects by nicotine on selective circuits and to define the overall impact on striatal output, field potential recordings were conducted in the dorsolateral striatum (DLS) and combined with optogenetics and whole-cell patch-clamp recordings.

\section{Materials and Methods}

Experimental design. The overall aim with this study was to define acute effects mediated by nicotine on neurotransmission and synaptic output from the DLS, a key brain region with respect to the formation of habits. To this end, a battery of ex vivo electrophysiological recordings combined with optogenetics were used in acutely isolated brain slices containing rat striatum. A systematic approach was conducted to access concentration dependency and the long-lasting effects by nicotine, after which pharmacological manipulations were performed to define the signaling pathways recruited by nicotine.

Drugs. Pharmacological agents targeting selective receptors were dissolved in appropriate solvent and diluted in aCSF to the final concentration shortly before use. The nAChR agonist 3-bromocyticine was dissolved in water to $5 \mathrm{~mm}$ and used at 10 or $500 \mathrm{~nm}$, whereas PNU 282987 was dissolved in DMSO to $50 \mathrm{~mm}$ and further diluted to $1 \mu \mathrm{M}$ in aCSF. The $\alpha 7$ nAChR antagonist methyllycaconitine citrate (MLA) was dissolved in $\mathrm{H}_{2} \mathrm{O}$ to $10 \mathrm{~mm}$ and used at $40 \mathrm{~nm}$, the $\alpha 6 \mathrm{nAChR}$ antagonist $\alpha$-conotoxin PIA was dissolved in $\mathrm{H}_{2} \mathrm{O}$ to $200 \mu \mathrm{M}$ and diluted in aCSF to
$10 \mathrm{~nm}$, the $\alpha 4 \beta 2 \mathrm{nAChR}$ antagonist dihydro- $\beta$-erythroidine hydrobromide (DH $\beta \mathrm{E}$ ) was dissolved in $\mathrm{H}_{2} \mathrm{O}$ to $22 \mathrm{~mm}$ and used at $1 \mu \mathrm{M}$, the $\mathrm{CB} 1 \mathrm{R}$ antagonist AM251 was dissolved in DMSO to $20 \mathrm{mM}$ and used at $2 \mu \mathrm{M}$, the NMDA receptor antagonist APV was dissolved in $\mathrm{H}_{2} \mathrm{O}$ to $50 \mathrm{~mm}$ and diluted to $50 \mu \mathrm{M}$ in aCSF, whereas the AMPA receptor antagonist CNQX was dissolved in $\mathrm{H}_{2} \mathrm{O}$ to $20 \mathrm{~mm}$ and further diluted to $10 \mu \mathrm{M}$. The muscarinic acetylcholine receptor (mAChR) agonist oxotremorine sesquimufarate (Oxo) was dissolved in $\mathrm{H}_{2} \mathrm{O}$ to $25 \mathrm{~mm}$ and administered at $10 \mu \mathrm{M}$, whereas the dopamine $\mathrm{D} 2$ receptor agonist quinpirole hydrochloride was dissolved in $\mathrm{H}_{2} \mathrm{O}$ to $80 \mathrm{~mm}$ and used at $5 \mu \mathrm{M}$. The L-type calcium channel inhibitor nifedipine was dissolved in DMSO to $100 \mathrm{~mm}$ and further diluted in aCSF to $20 \mu \mathrm{M}$. All above substances were purchased from Tocris Bioscience. (-)-Nicotine hydrogen tartrate salt was dissolved to final concentration ( $10 \mathrm{~nm}$ to $10 \mu \mathrm{M})$ in aCSF shortly before use, whereas the nonselective $\mathrm{nAChR}$ antagonist mecamylamine hydrochloride was dissolved to $50 \mathrm{~mm}$ in $\mathrm{H}_{2} \mathrm{O}$ and applied at 0.5 or $10 \mu \mathrm{M}$. The $\mathrm{GABA}_{\mathrm{A}}$ receptor antagonist bicuculline methiodide was dissolved in $\mathrm{H}_{2} \mathrm{O}$ to $20 \mathrm{~mm}$ and further diluted in aCSF to $20 \mu \mathrm{M}$. The dopamine D1 receptor antagonist $\mathrm{SCH} 23390$ was dissolved in $\mathrm{H}_{2} \mathrm{O}$ to $10 \mathrm{~mm}$ and used at $0.5 \mu \mathrm{M}$, whereas the dopamine D2 receptor antagonist sulpiride was dissolved in ethanol to $20 \mathrm{~mm}$ and used at $5 \mu \mathrm{M}$. Scopolamine hydrobromide was dissolved in aCSF $(10 \mu \mathrm{M})$ shortly before use. All above substances were purchased from Sigma-Aldrich.

Brain slice preparation. Brain slices were prepared from juvenile male RCC Han Wistar rats P28-P42 and adult Wistar rats (14-16 weeks old, $300 \mathrm{~g}$ ) (Envigo), as previously described in detail (Clarke and Adermark, 2010). In brief, animals were anesthetized with isoflurane and the brain quickly removed and submerged in ice-cold modified aCSF consisting of the following (in mM): 220 sucrose, $2 \mathrm{KCl}, 6 \mathrm{MgCl}_{2}, 26 \mathrm{NaHCO}_{3}, 1.3$ $\mathrm{NaH}_{2} \mathrm{PO}_{4}, 0.2 \mathrm{CaCl}_{2}$, and 10 D-glucose, continuously bubbled with a gas mixture of $95 \% \mathrm{O}_{2} / 5 \% \mathrm{CO}_{2}$. Brains were sectioned coronally at $250-350$ $\mu \mathrm{m}$ using a VT $1200 \mathrm{~S}$ Vibratome (Leica Microsystems). The slices were transferred to a custom-made incubation chamber with conventional aCSF containing the following (in mM): $124 \mathrm{NaCl}, 4.5 \mathrm{KCl}, 2 \mathrm{CaCl}_{2}, 1 \mathrm{MgCl}_{2}, 26$ $\mathrm{NaHCO}_{3}, 1.2 \mathrm{NaH}_{2} \mathrm{PO}_{4}$, and 10 D-glucose, with osmolarity adjusted to 315 320 mOsm with sucrose, and continuously bubbled with $95 \% \mathrm{O}_{2} / 5 \% \mathrm{CO}_{2}$. Slices were incubated in aCSF for $30 \mathrm{~min}$ at $30^{\circ} \mathrm{C}$ and at room temperature for the remainder of the day. Experiments were approved by the Ethics Committee for Animal Experiments, Gothenburg, Sweden.

Field potential recordings. Field potential recordings were performed as previously described (Adermark et al., 2011b). In brief, one hemisphere slice was placed in the recording chambers under constant flow of preheated aCSF $\left(30^{\circ} \mathrm{C}, 2 \mathrm{ml} / \mathrm{min}\right)$. A stimulating electrode (monopolar tungsten electrode, type TM33B, World Precision Instruments) was placed at the border of the subcortical white matter and the striatum, and population spikes (PSs) were evoked using a paired-pulse stimulation protocol with a $50 \mathrm{~ms}$ interpulse interval evoked at a frequency of 0.05 Hz. Stimulus intensity $(0.01-0.04 \mathrm{~mA})$ was adjusted so that the PS amplitude was approximately half the size of the maximal response. Signals were amplified by a custom-made amplifier, filtered at $3 \mathrm{kHz}$, and digitized at $8 \mathrm{kHz}$. Data were analyzed with Clampfit 10.2 (Molecular Devices) and GraphPad Prism (GraphPad Software). A stable baseline was monitored for at least 10 min before drug administration. In all recordings where antagonists/agonists were administered before nicotine, slices were pretreated for at least $20 \mathrm{~min}$ and then continuously throughout the experiment. In one set of experiments, endocannabinoid-mediated LTD was induced by high frequent stimulation (HFS) (4 trains of 100 pulses delivered at $100 \mathrm{~Hz}$ with a $4 \mathrm{~s}$ intertrain interval) as previously described (Adermark and Lovinger, 2009). Responses with a PS amplitude $<0.2$ $\mathrm{mV}$ at baseline were excluded. In the displayed graphs, each data point is presented as mean amplitude of 3 PSs recorded over $1 \mathrm{~min}$.

Whole-cell patch-clamp recordings. Striatal brain slices from juvenile rats were placed in a recording chamber under constant flow of preheated aCSF $\left(33^{\circ} \mathrm{C}-34^{\circ} \mathrm{C}, 2 \mathrm{ml} / \mathrm{min}\right)$. The region was identified using a $10 \times / 0.30 \mathrm{objec}-$ tive attached to a Nikon Eclipse FN-1 microscope, whereas a $40 \times / 0.80$ water-immersion objective was used to localize MSNs for whole-cell recordings. Recording pipettes were prepared from borosilicate glass (outer diameter, $1.5 \mu \mathrm{m}$, Sutter Instruments) and pulled to a resistance between 2.5 and $4.5 \mathrm{M} \Omega$ using a micropipette puller (model P-97, Sutter Instruments). 
A

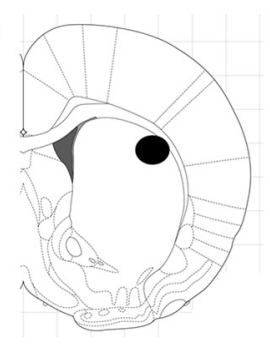

B

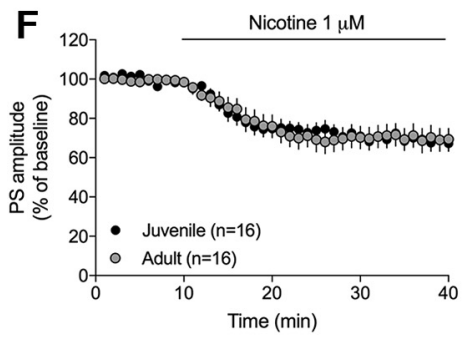

C

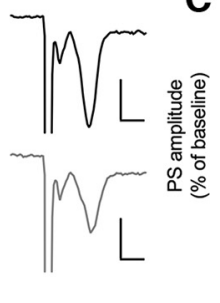

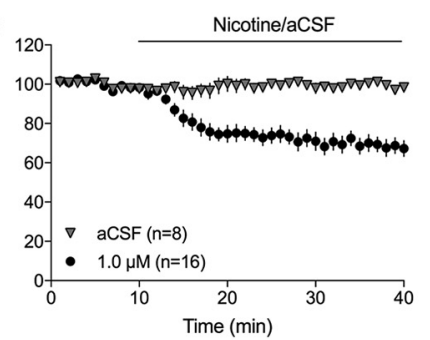
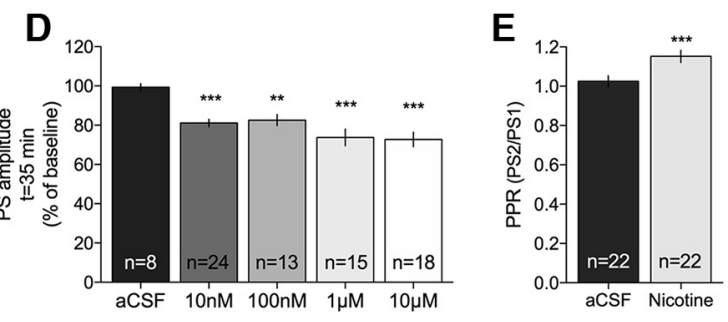
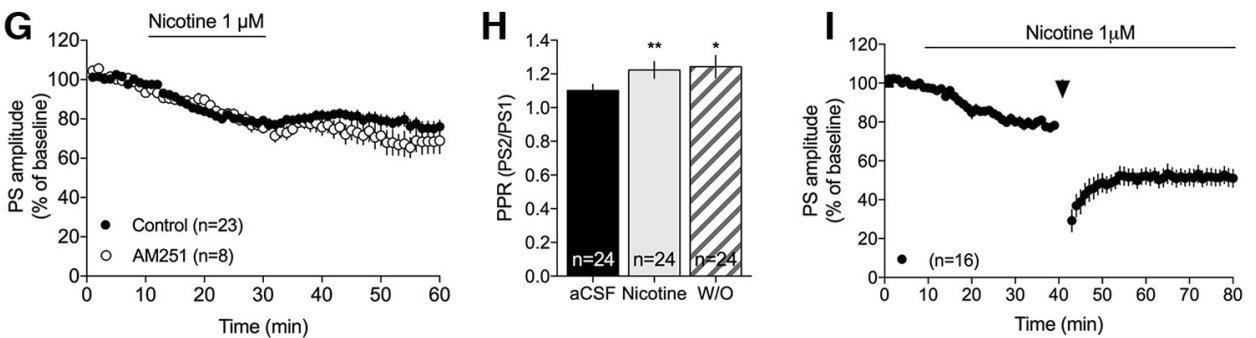

Figure 1. Nicotine suppresses PS amplitude. $\boldsymbol{A}$, Schematic drawing showing the area in the DLS where recordings were performed. $\boldsymbol{B}$, Representative traces represent evoked PSs at baseline (black) and following nicotine perfusion (gray). Calibration: $0.2 \mathrm{mV}, 2 \mathrm{~ms}$. C, Nicotine depressed PS amplitude in DLS compared with continuous perfusion with aCSF. D, Bar graphs represent PS amplitudes following $25 \mathrm{~min}$ of administration of different concentrations of nicotine. $\boldsymbol{E}$, The decrease in PS amplitude induced by $1 \mu \mathrm{m}$ nicotine was concomitant with an increase in PPR, indicative of reduced probability for transmitter release. $\boldsymbol{F}$, Nicotine depressed evoked PS amplitude to a similar extent in brain slices from adult rats $(>300 \mathrm{~g}) . \mathbf{G}$, The effect displayed by $1 \mu \mathrm{m}$ nicotine sustained during drug washout, both in slices pretreated with the CB1R antagonist AM251 and controls. $\boldsymbol{H}$, The increase in PPR sustained also during drug washout. I, Nicotine-induced LTD did not occlude LTD induced by HFS. Arrow indicates time point for HFS. Graphs represent mean PS amplitude \pm SEM over time. $n=$ the number of recordings, performed in slices from rats from at least three different litters. ${ }^{*} p<0.05$, significant compared with baseline. ${ }^{* *} p<0.01$, significant compared with baseline. ${ }^{* *} p<0.001$, significant compared with baseline.

Current-clamp recordings were conducted to define acute effects displayed by nicotine on MSN excitability. Pipettes for current-clamp recordings were filled with a solution containing the following (in mM): 135 potassium gluconate, $5 \mathrm{EGTA}, 0.5 \mathrm{CaCl}_{2}, \mathrm{MgCl}_{2}, 10 \mathrm{HEPES}, 2 \mathrm{MgATP}$, $0.1 \mathrm{GTP}, \mathrm{pH}$ adjusted to 7.3 with $\mathrm{KOH}$, and osmolarity to $278 \mathrm{mOsm}$ with sucrose. Current steps of $250 \mathrm{~ms}$ duration and ranging in intensity from -80 to $320 \mathrm{pA}$, with incremental steps of $20 \mathrm{pA}$, were injected to hyperpolarize and depolarize the cell membrane and measure voltage changes. A number of parameters, including capacitance, resting membrane potential, action potential (AP) threshold, rheobase, AP latency and frequency, were assessed during baseline (aCSF perfusion) and following $10 \mathrm{~min}$ of bath-application of nicotine $(1 \mu \mathrm{M})$.

In other sets of slices, sIPSCs or sEPSCs were recorded in MSNs voltage-clamped at $-65 \mathrm{mV}$. The same internal solution was used for both types of measurements and contained the following (in $\mathrm{mM}$ ): 150 $\mathrm{CsCl}, 10$ HEPES, $2 \mathrm{MgCl}_{2}, 0.3 \mathrm{Na}_{2} \mathrm{GTP}, 3 \mathrm{MgATP}$, and 0.2 BAPTA, with $\mathrm{pH}$ adjusted to 7.2 with $\mathrm{CsOH}$, and osmolarity set to $298 \mathrm{mOsm}$ with sucrose. To record sIPSCs, $50 \mu \mathrm{M}$ AP5 and $10 \mu \mathrm{M}$ CNQX were added to the aCSF to block NMDA and AMPA receptor-mediated currents, whereas $20 \mu \mathrm{M}$ bicuculline was added during measurement of sEPSCs. After initiation of the whole-cell recording, stable baseline responses were observed over 5-10 min; and after 5 additional minutes of baseline recording, $1 \mu \mathrm{M}$ nicotine was perfused for $10 \mathrm{~min}$ followed by drug washout.

Whole-cell recordings were conducted with an Axopatch 700B amplifier (Molecular Devices), filtered at $2 \mathrm{kHz}$, and digitized at $5 \mathrm{kHz}$. Data were acquired using Clampex 10.2. Only recordings with a stable series resistance that varied $<20 \%$ and did not exceed $25 \mathrm{M} \Omega$ were included in the analysis. Off-line analysis of current-clamp recordings, sIPSCs, and sEPSCs was performed using Clampex 10.2, Minianalysis 6.0 (Synaptosoft) and Graph Pad Prism.

Optogenetic recordings. Optogenetic control over fast-spiking interneuron (FSI) transmitter release was performed as previously described (Patton et al., 2016). Briefly, Pvalb-cre mice ( $>2$ months old, bred at University of Maryland) were injected with a double-floxed, AAV viral vector containing DIO-ChR2-mCherry under an EF1a promoter (AAVflox-DIO-ChR2-mCherry) into the DLS (anteroposterior $0.6 \mathrm{~mm}$, mediolateral $\pm 2.25 \mathrm{~mm}$, dorsoventral $-2.4 \mathrm{~mm}$ from bregma) and allowed to recover for at least 3 weeks before brains were removed for acute slice electrophysiology (Mathur et al., 2013). During the experiments, slices were constantly perfused with carbogen-bubbled aCSF at $30^{\circ} \mathrm{C}\left( \pm 1^{\circ} \mathrm{C}\right)$ and nicotine applied to slices via a gravity perfusion system. Whole-cell voltage-clamp recordings were made from visually identified MSNs located in the infection zone using borosilicate glass pipettes. Pipettes used were in the $2-5 \mathrm{M} \Omega$ resistance range and filled with a $\mathrm{CsCl}$-based internal solution (150 mм CsCl, 10 mм HEPES, 2 mм $\mathrm{MgCl}_{2}$, $0.3 \mathrm{~mm} \mathrm{Na-GTP,} 5$ mM QX-314, 3 mm Mg-ATP, and $0.2 \mathrm{~mm}$ BAPTA) at a pH of 7.3 and osmolarity ranging from 305 to $310 \mathrm{mOsm}$. Blue light pulses $(470 \mathrm{~nm}$, 2-4 ms pulse duration) were delivered every $20 \mathrm{~s}$ using epifluorescent LED field illumination (Lumen Dynamics, XLED1) to elicit optically evoked IPSCs (oIPSCs) in MSNs that were voltage-clamped at $-60 \mathrm{mV}$ using a MultiClamp 700B amplifier (Molecular Devices). Recordings were digitized at $10 \mathrm{kHz}$ and filtered at $2 \mathrm{kHz}$ using Clampex (Molecular Devices). Any changes in series resistance that exceeded 15\% resulted in the exclusion of that cell from analysis. Mean oIPSC amplitudes were averaged per minute and expressed as a percentage change from average baseline oIPSCs.

Statistical analysis. Statistical analysis was performed using Graph Pad Prism 7. Gaussian distribution was tested with the D'Agostino and Pearson omnibus normality test. Data are presented as mean \pm SEM, and the level of significance was set to $p<0.05$. Group effects and treatment effects were analyzed using two-way ANOVA, Komolgorov-Smirnov test, or $t$ test when applicable.

\section{Results}

\section{Nicotine administration suppresses PS amplitude in a} long-lasting manner

Changes in dorsal striatal neurotransmission induced by bath perfusion of nicotine were assessed by field potential recordings. Administration of nicotine (10 $\mathrm{nM}$ to $10 \mu \mathrm{M})$ significantly depressed evoked PSs (two-way ANOVA $_{15-40}$ min nicotinetreatment vs aCSF: $10 \mathrm{nM}\left(F_{(1,30)}=21.7, p<0.001 ; 100 \mathrm{nM}: F_{(1,13)}=\right.$ 9.32, $p=0.009 ; 1 \mu \mathrm{M}: F_{(1,21)}=14.3, p=0.001 ; 10 \mu \mathrm{M}: F_{(1,22)}=$ $17.8, p<0.001$ ) (Fig. $1 C, D)$. The decrease in PS amplitude was accompanied by an increase in PPR, indicative of reduced probability for transmitter release $\left(1 \mu \mathrm{M}\right.$ nicotine: $t_{(19)}=4.82, p<$ $0.001)$ (Fig. $1 E)$. Nicotine $(1 \mu \mathrm{M})$ produced a similar effect when administered to brain slices from adult Wistar rats $(>3$ months 

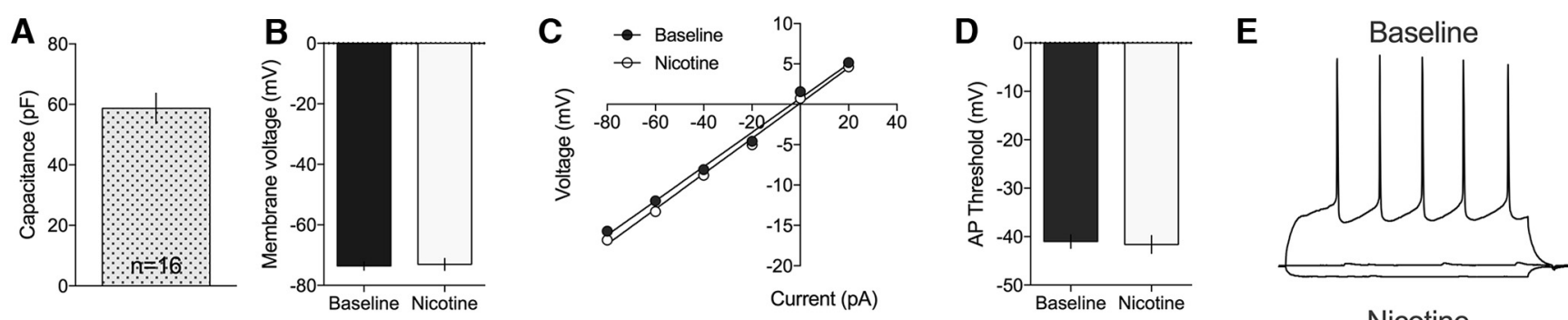

Nicotine
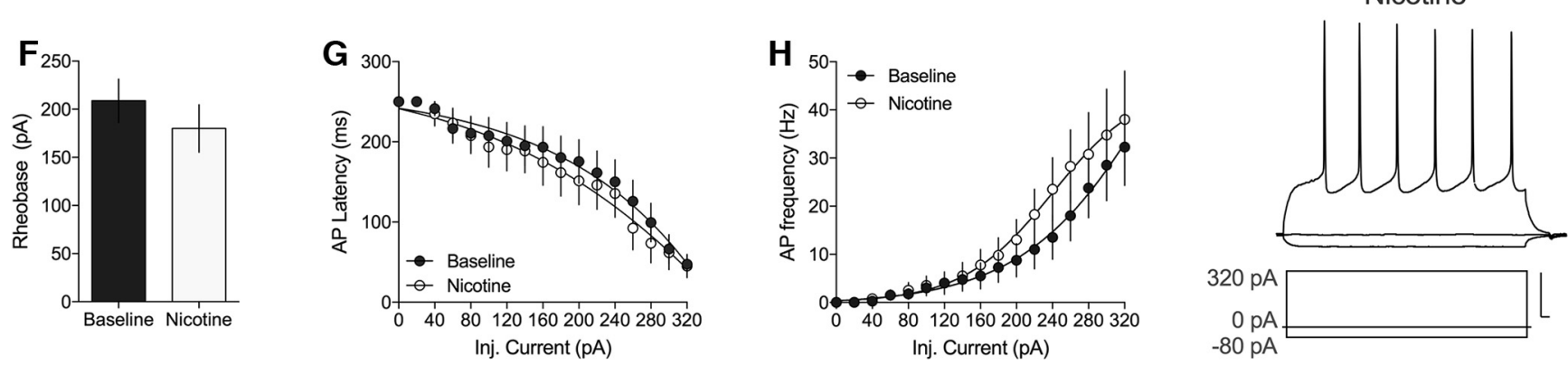

Figure 2. MSN excitability is not affected by nicotine. Current-clamp recordings showed no significant effect on MSN membrane properties or AP firing in response to nicotine exposure. $A$, The membrane capacitance from the recorded cells $(n=16)$ corresponded well with values previously reported for MSNs. $B, C$, Ten minutes administration of nicotine (1 $\mu \mathrm{m})$ did not significantly modulate membrane voltage or $I-V$ relationship compared with baseline. $\boldsymbol{D}$, The threshold for AP firing was not modulated by nicotine administration. $\boldsymbol{E}$, Representative traces of current-clamp recordings at baseline and following $10 \mathrm{~min}$ of nicotine exposure. Calibration: $20 \mathrm{mV}, 10 \mathrm{~ms}$. $\boldsymbol{F}-\boldsymbol{H}$, Administration of nicotine did furthermore not influence Rheobase, AP latency, or AP frequency. Data are mean \pm SEM, and based on 16 cells taken from rats from at least three different litters.

old) compared with juvenile rats (P21-P35) (juvenile vs adult: $\left.F_{(1,29)}=2.04, p>0.05\right)($ Fig. $1 F)$.

Nicotine induced an LTD of PS amplitude that sustained during drug washout (Fig. 1G). The increase in PPR induced by nicotine also remained following nicotine washout (drug $20 \mathrm{~min}$ wash on: $t_{(22)}=4.54, p<0.001 ; 20$ min wash off: $t_{(22)}=2.50, p=$ 0.020 ; wash on vs wash off: $t_{(22)}=0.37, \mathrm{df}=22, p>0.05$ ) (Fig. $1 H)$. Neither the acute depression nor nicotine-induced LTD was inhibited in slices pretreated with the cannabinoid 1 receptor $(\mathrm{CB} 1 \mathrm{R})$ antagonist AM251 $(2 \mu \mathrm{M})\left(F_{(1,32)}=1.09, p>0.05\right.$; Fig. $1 G)$. Furthermore, nicotine did not occlude LTD induced by HFS (paired $t$ test: $t_{(15)}=4.48, p<0.001$; Fig. $1 I$ ). Endocannabinoidmediated LTD, which has previously been shown to be regulated by nAChRs (Partridge et al., 2002; Adermark, 2011; Adermark et al., 2018), does thus not underlie nicotine-induced LTD.

\section{Nicotine does not alter excitability of MSNs}

To determine whether nicotine modulates PS amplitude by altering MSN excitability, whole-cell recordings were performed in current-clamp mode. MSNs had a mean capacitance of $59 \pm 4.98$ pf $(n=16)$ (Fig. 2A), which is in line with previous studies (Dorris et al., 2015). Ten minutes perfusion of nicotine $(1 \mu \mathrm{M})$ did not significantly alter membrane voltage potential $\left(t_{(15)}=\right.$ $0.41, p>0.05$; Fig. $2 B)$ or $I-V$ relationship $\left(t_{(15)}=1.46, p>0.05\right.$; Fig. $2 C$ ). In addition, when monitoring active membrane properties, there were no significant effects by nicotine on AP threshold $\left(t_{(13)}=0.26, p=0.79\right)$, Rheobase $\left(t_{(14)}=1.56, p=0.14\right)$, AP latency $\left(F_{(1,29)}=0.20, p=0.65\right)$, or AP frequency $\left(F_{(1,30)}=0.64\right.$, $p=0.43$ ) (Fig. 2). Nicotine may thus primarily modulate striatal neurotransmission by altering presynaptic inputs onto MSNs.

Nicotine selectively modulates excitatory inputs on to MSNs PS amplitude is tightly regulated by inhibitory neurotransmission, and activation of nAChRs has previously been shown to increase the firing of FSIs (Luo et al., 2013). FSI-MSN connectivity was assessed by measuring IPSCs in MSNs evoked by optoge- netic activation of FSIs (oIPSCs) (Fig. 3A). Light-evoked oIPSCs were, however, not significantly enhanced by nicotine administration (PS amplitude at $t=25-30 \mathrm{~min}: 115 \pm 15.5 \%$ of baseline, $\left.t_{(8)}=0.98, p>0.05\right)$, suggesting that increased FSI-MSN connectivity is not the primary cause of depressed PS amplitude following nicotine exposure (Fig. 3B). To determine whether other subtypes of GABAergic cells could be involved in mediating nicotine-induced suppression of striatal neurotransmission, sIPSCs were recorded in MSNs. However, 10 minutes administration of nicotine $(1 \mu \mathrm{M})$ did not alter recorded sIPSCs (sIPSC frequency: $98 \pm 4.9 \%$ of baseline, $t_{(21)}=0.35, p>0.05$; sIPSC amplitude: $99 \pm 1.7 \%$ of baseline, $t_{(21)}=0.79, p>0.05$ ) (Fig. 3). Nicotine had also no effect on the cumulative distributions of either event intervals or amplitudes (Komolgorov-Smirnov test: event intervals: $D=0.07, p=0.09$; amplitude: $D=0.06, p=0.20$ ) (Fig. $3 J, K)$. In addition, pretreatment with the $\mathrm{GABA}_{\mathrm{A}}$ receptor antagonist bicuculline was insufficient to block nicotine-induced LTD $\left(F_{(1,31)}=0.18, p>0.05\right)$ (Fig. 3L).

Contrasting the lack of effect by nicotine on recorded sIPSCs, sEPSC frequency was significantly decreased following a $10 \mathrm{~min}$ bath perfusion of $1 \mu \mathrm{M}$ nicotine $\left(77 \pm 3.9 \%\right.$ of baseline, $t_{(23)}=$ 5.77, $p<0.001$ ) (Fig. $4 F$ ), whereas amplitude remained unaffected ( $97 \pm 2.7 \%$ of baseline, $t_{(23)}=1.23, p>0.05$ ) (Fig. $4 G$ ). The depressant effect by nicotine on sEPSC frequency sustained during drug washout $\left(77 \pm 10.2 \%\right.$ of baseline, $t_{(13)}=2.28, p=$ 0.04) (Fig. $4 F$ ). Nicotine furthermore modulated the cumulative distributions of interevent intervals but had no effect on amplitudes (Komolgorov-Smirnov test: event intervals: $D=0.11, p<$ 0.001; amplitude: $D=0.05, p=0.92$ ) (Fig. $4 H, I$ ). Nicotine thus appears to suppress PS amplitude by reducing the frequency of excitatory inputs onto MSNs in a long-lasting manner.

nAChR subtypes mediating nicotine-induced suppression of PS amplitude

nAChR subtypes are expressed on different neuronal populations, thereby exerting a complex modulation of striatal output. 

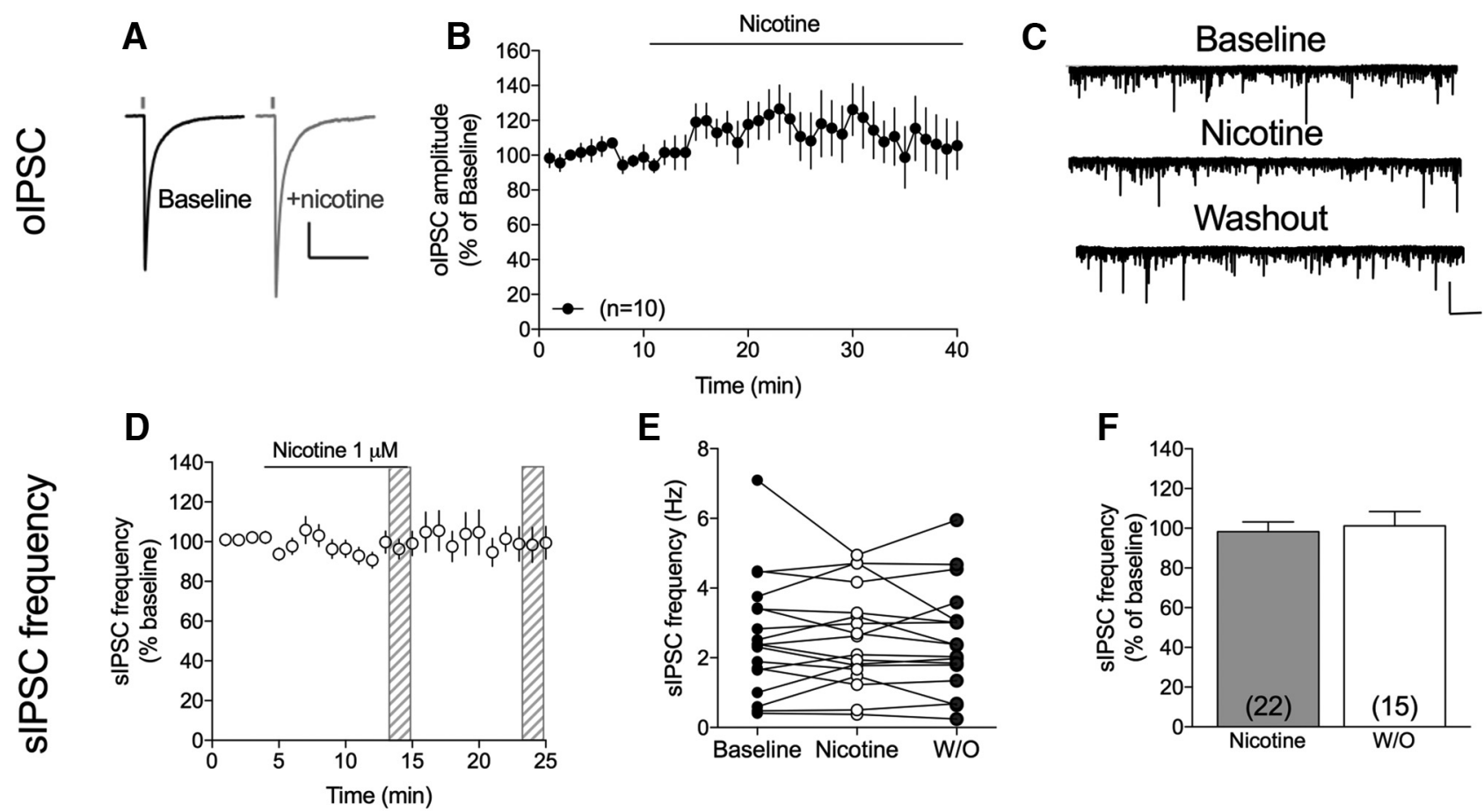

E
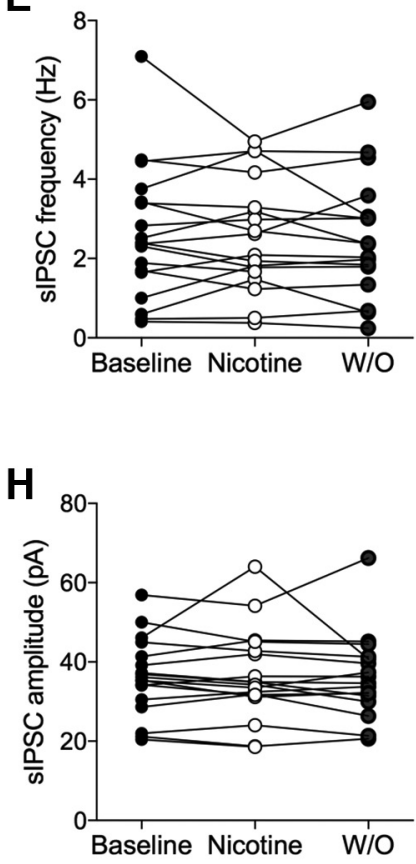
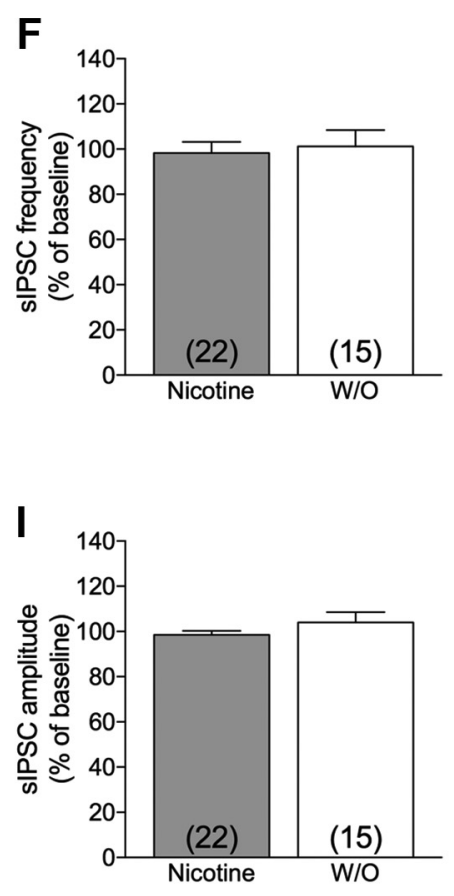
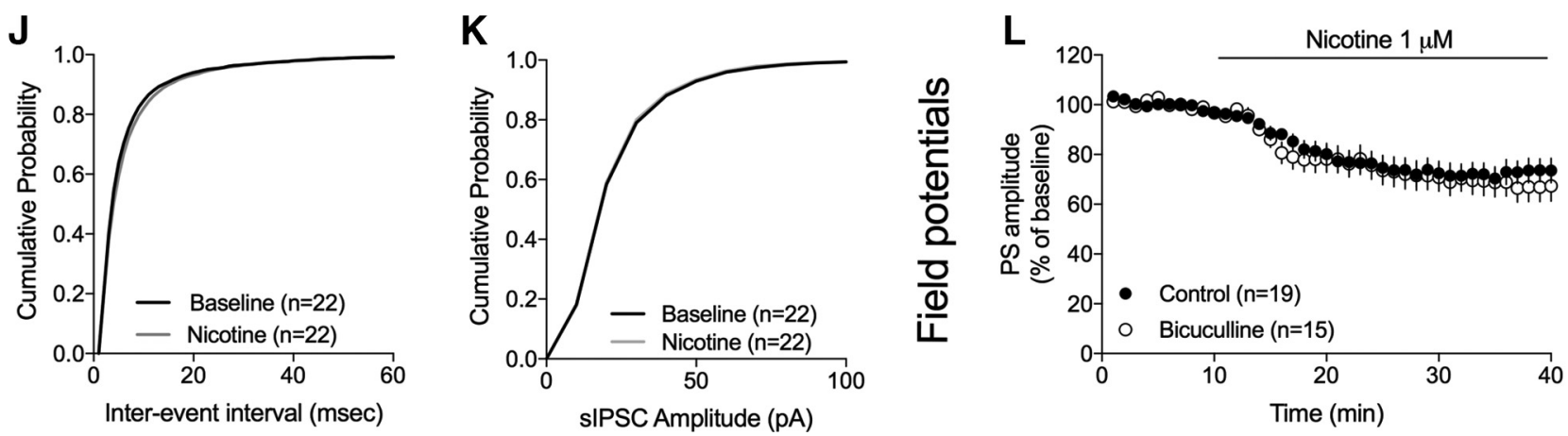

Figure 3. Nicotine does not suppress PS amplitude by enhancing GABAergic neurotransmission. $A$, Representative traces show IPSCs in a MSNs evoked by optogenetic activation of FSIs at baseline (black) and following nicotine administration (gray). Calibration: 200 pA, 200 ms. B, Time course graph showing olPSCs in MSNs from mouse DLS. Nicotine did not significantly increase FSI-DLS connectivity. C, Representative traces showing measured sIPSCs at baseline, following 10 min perfusion of nicotine, and during washout. Calibration: 100 pA, 10 s. D, Time course figures showing relative frequency of recorded sIPSCs before, during, and after nicotine perfusion. $E$, Scatterplot showing sIPSC frequency in individual neurons at baseline, following $10 \mathrm{~min}$ of nicotine perfusion, and after $10 \mathrm{~min}$ washout (W/O). $\boldsymbol{F}$, Bar graph represents mean change in sIPSC frequency induced by $10 \mathrm{~min}$ of exposure to nicotine. $\boldsymbol{G}$, Scatterplot describes sIPSC amplitude at baseline and after 10 min of nicotine administration in individual neurons. $\boldsymbol{H}$, Time course graph represents relative sIPSC amplitude during nicotine administration. $\boldsymbol{I}$, Bar graphs represent mean change in sIPSC amplitude induced by 10 min of exposure to nicotine and following washout. $J, K$, Nicotine had no effect on the cumulative distributions of either event intervals or amplitudes. $L$, Pretreatment with the $G A B A_{A}$ receptor antagonist bicuculline did not prevent the nicotine-induced LTD of evoked PSs. Time course graphs represent mean values \pm SEM over time. $n=$ the number of cells, taken from rats from at least three different litters. 

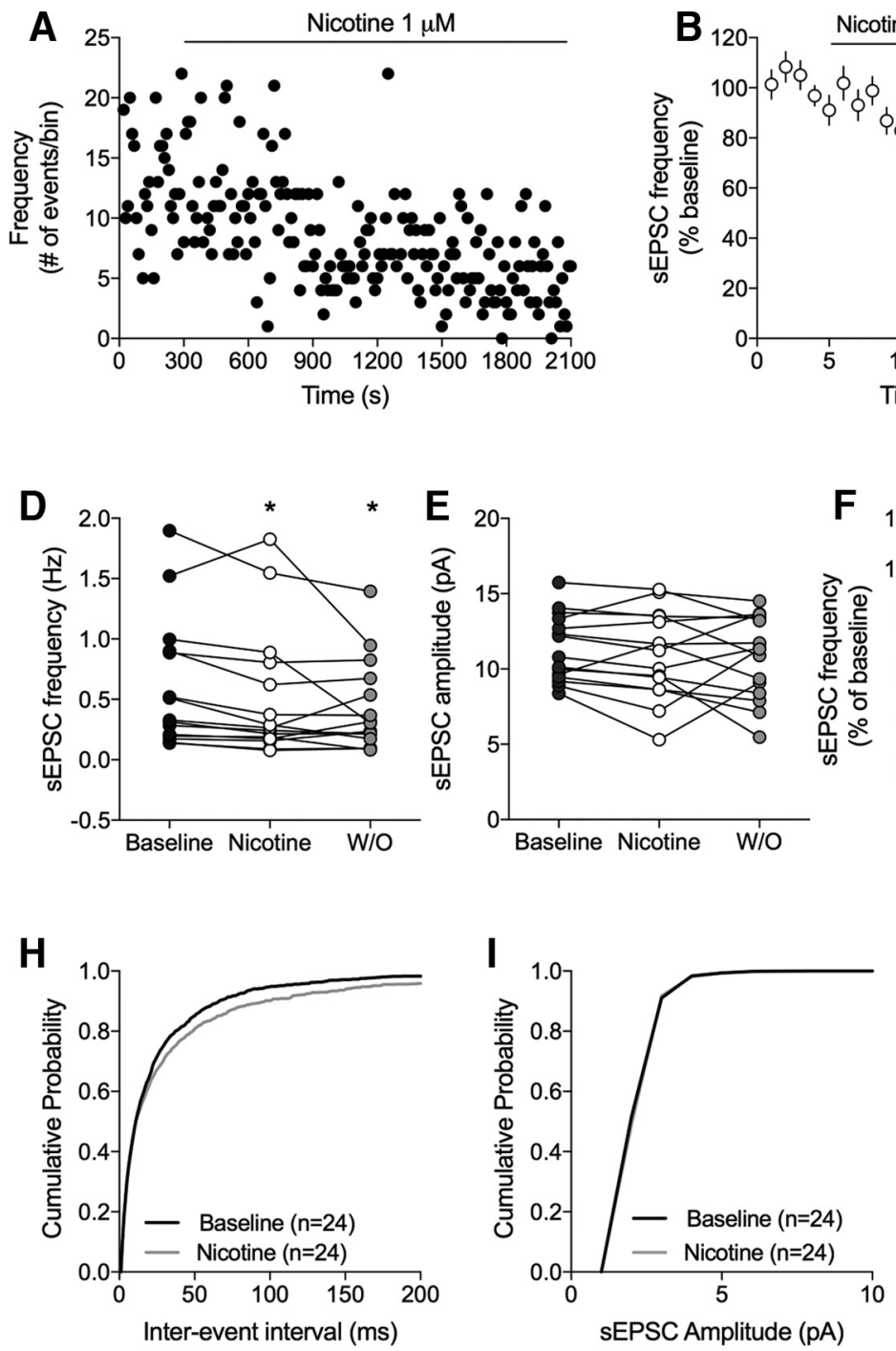
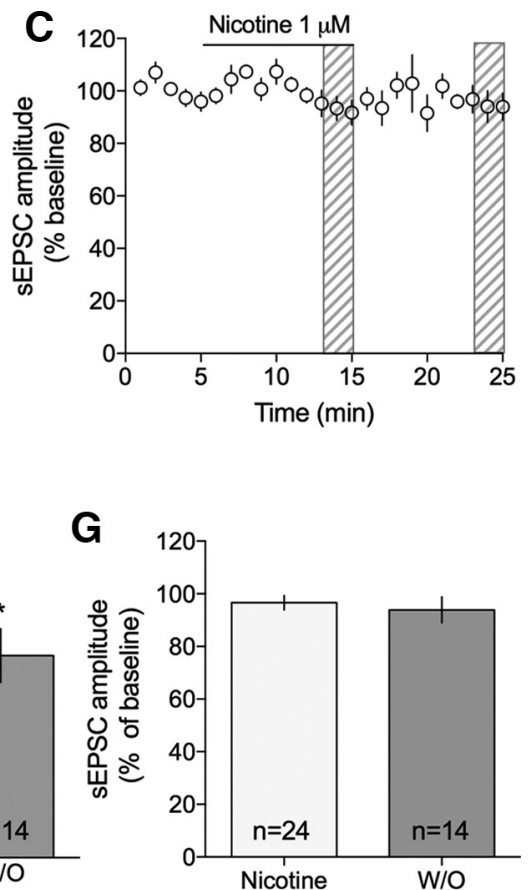

Figure 4. Nicotine suppresses the frequency of excitatory inputs to MSNs. $\boldsymbol{A}$, Time course graph showing sEPSC frequency in an example cell during continuous nicotine perfusion (1 $\mu$ m). $\boldsymbol{B}, \boldsymbol{C}$, Graphs represent relative sEPSC frequency and amplitude over time. $\boldsymbol{D}, \boldsymbol{E}$, Scatterplots shows sEPSC frequency and amplitude at baseline, following 10 min of nicotine perfusion, and after 10 min washout (W/0) in individual neurons. $\boldsymbol{F}, \mathbf{G}$, Bar graphs represent mean change in sEPSC frequency and amplitude induced by 10 min exposure to nicotine. $\boldsymbol{H}, \boldsymbol{I}$, Nicotine significantly modulated the cumulative distribution of interevent intervals but had no effect on amplitudes. J, Representative traces show recorded sEPSCs at baseline, following 10 min of nicotine, and after 10 min washout. Calibration: 40 pA, 2 s. $n=$ the number of cells taken from rats from at least three different litters. ${ }^{*} p<0.05$, significant compared with baseline. ${ }^{* * *} p<0.001$, significant compared with baseline.

Administration of the wide-spectrum blocker mecamylamine did not prevent nicotine-induced suppression of recorded sEPSCs (frequency: $t_{(4)}=5.57, p=0.005$; amplitude: $t_{(4)}=0.65$, $p>0.05$ ) (Fig. 5A). Nicotine did also produce a similar depression of recorded field potentials in slices pretreated with mecamylamine (nicotine vs mecamylamine+ nicotine: $F_{(1,23)}=0.04$, $p>0.05$ ) (Fig. 5B). To define the receptor subtype involved in mediating nicotine-induced suppression of PS amplitude, brain slices were perfused with more selective antagonists and agonists. $\alpha 7$-containing nAChRs is the primary subtype expressed on glutamatergic terminals, and the $\alpha 7$-specific agonist PNU 282987 $(1 \mu \mathrm{M})$ significantly suppressed PS amplitude $\left(F_{(1,29)}=14.9, p<\right.$ $0.001)$ and increased PPR $\left(t_{(25)}=2.15, p=0.041\right)$ (Fig. 5C,D). Pretreatment with the $\alpha 7$-specific antagonist MLA (40 nM) blocked PNU 282987-induced depression $\left(F_{(1,36)}=16.8, p<\right.$ 0.001 ), with a combination of mecamylamine and MLA not having any additional effect $\left(F_{(1,36)}=2.02, p>0.05\right)$ (Fig. $5 C$ ). However, MLA did not prevent nicotine-induced depression of PS amplitude $\left(F_{(1,30)}=1.30, p>0.05\right)($ Fig. $5 F)$, suggesting that other subtypes might additionally contribute to nicotineinduced LTD. Administration of a low concentration of the nAChR agonist 3-bromocytisine (10 nM), which should act selectively on $\alpha 4 \beta 2$-containing $\mathrm{nAChRs,} \mathrm{also} \mathrm{produced} \operatorname{LTD}\left(F_{(1,24)}=\right.$ 49.7, $p<0.001$; PPR: $t_{(15)}=2.47, p=0.026$ ) (Fig. 5G,H). Synaptic depression induced by 3-bromocytisine was blocked by a low dose of mecamylamine $(0.5 \mu \mathrm{M})\left(F_{(1,15)}=8.89, p=0.01\right.$; Fig. $5 G)$, supporting a specific interaction with $\beta 2$-containing $n A C h R s$. However, pretreatment with the more selective antagonist $\mathrm{DH} \beta \mathrm{E}(1 \mu \mathrm{M})$, which should primarily inhibit $\alpha 4 \beta 2$ containing nAChRs, was also insufficient to block the depressant effect by nicotine $\left(F_{(1,45)}=3.47, p>0.05\right)$ (Fig. $\left.5 F\right)$. Interestingly, a higher concentration of 3-bromocytisine (500 nM), which should activate both $\alpha 4 \beta 2$ - and $\alpha 7$-containing nAChRs, did not produce an additive effect on evoked PSs $\left(500 \mathrm{nM}: F_{(1,25)}=15.7\right.$, $p<0.001 ; 10 \mathrm{~nm}$ vs $500 \mathrm{nM}: F_{(1,32)}=1.28, p>0.05$ ) (Fig. $5 I$ ). In addition, a combination of bromocytisine and PNU $282987 \mathrm{did}$ not further depress PS amplitude (500 nM 3-bromocytisine vs 10 $\mathrm{nM}+$ PNU 282987: $F_{(1,37)}=1.29, p>0.05$ (Fig. 5I). At the same 

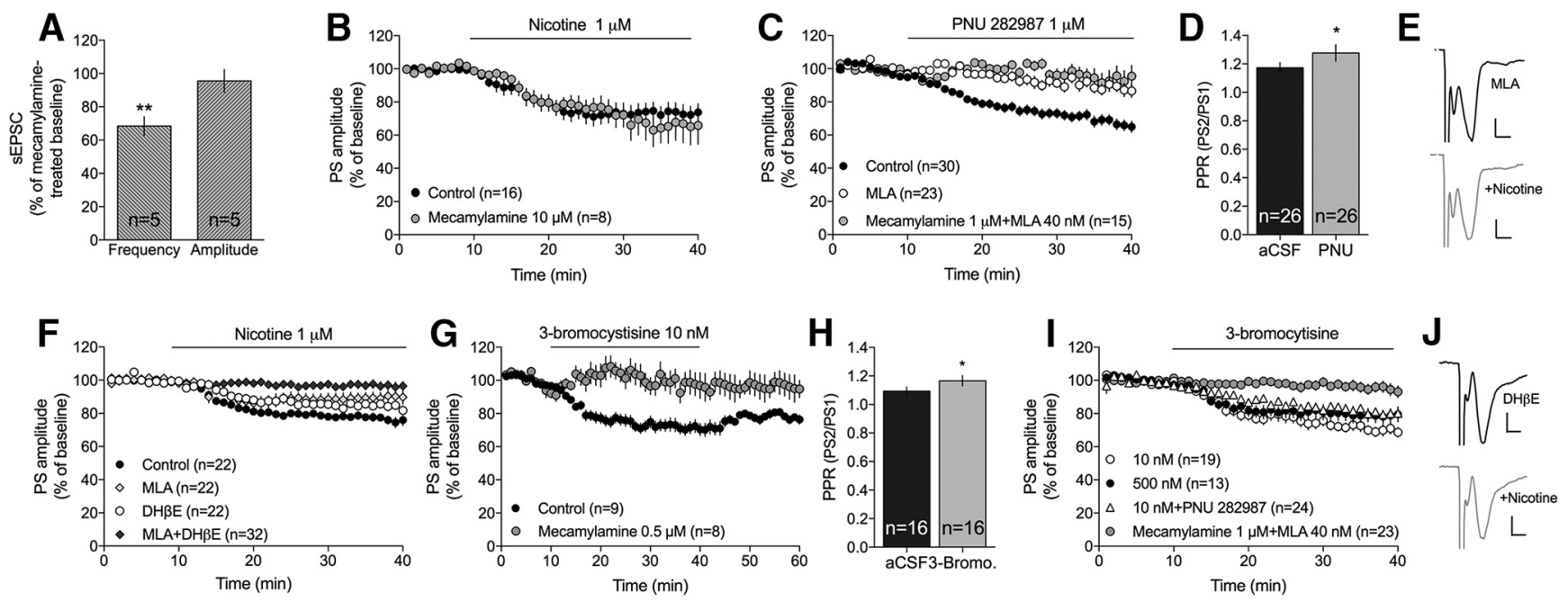

Figure 5. Nicotine induces LTD via activation of $\alpha 7$ - and $\alpha 4$-containing $n A C h R s$. $A$, The broad-spectrum $n A C h R$ antagonist mecamylamine did not prevent nicotine-induced depression of sEPSC frequency. $\boldsymbol{B}$, Nicotine $(1 \mu \mathrm{M})$ depressed PS amplitude to a similar extent in mecamylamine-pretreated slices. $\boldsymbol{C}, \boldsymbol{D}$, Administration of the $\alpha 7$-specific agonist PNU 282987 depressed PS amplitude and enhanced PPR in a manner that was blocked by MLA.E, Example traces showing evoked PSs at MLA-treated baseline (black) and following nicotine (gray). Calibration:0.2 mV, 2 ms. $F$, Combined inhibition of $\alpha 7$ - and $\alpha 4$-expressing nAChR was required to fully block nicotine-induced LTD. G, $\boldsymbol{H}$, A low concentration of 3-bromocytisine (10 nm), which should act selectively on $\alpha 4$-expressing nAChR, induced LTD and increased PPR, and was antagonized by mecamylamine. I, Neither a higher concentration of 3-bromocytisine (500 nM), which should activate both $\alpha 4$ - and $\alpha 7$-containing nAChRs, nor a combination of 3-bromocytisine and PNU 282987 produced an additive depression of PS amplitude. LTD induced by 3-bromocytisine (500 nm) was blocked in slices pretreated with mecamylamine combined with MLA. J, Example traces show evoked PSs at DH $\beta$ E-treated baseline (black) and following administration of nicotine (gray). Calibration: $0.2 \mathrm{mV}, 2 \mathrm{~ms}$. Time course graphs show mean PS amplitude \pm SEM over time. $n=$ the number of recordings, performed in slices from rats from at least three different litters. ${ }^{*} p<0.05$, significant compared with baseline. ${ }^{* *} p<0.01$, significant compared with baseline.

time, combined administration of MLA and DH $\beta$ E significantly inhibited nicotine-induced LTD $\left(F_{(1,41)}=18.4, p<0.001\right)$ (Fig. $5 F)$, supporting a combined effect mediated through $\alpha 4 \beta 2$ - and $\alpha 7$-containing nAChRs. MLA in combination with a low concentration of mecamylamine $(0.5 \mu \mathrm{M})$ also prevented LTD induced by either 3-bromocytisine (500 nM) (3-bromocytisine vs MLA + mecamylamine +3 -bromocytisine; $\left.F_{(1,33)}=14.2, p<0.001\right)$ (Fig. $5 I$ ), or $1 \mu \mathrm{M}$ nicotine (nicotine vs MLA + mecamylamine + nicotine: $\left.F_{(1,31)}=85, p<0.001\right)$ (data not shown).

\section{Signaling pathways contributing to nicotine-induced suppression of striatal neurotransmission}

Dopamine axon terminals in the striatum express a large diversity of nAChRs, allowing nicotine to regulate the probability of dopamine release (Rice and Cragg, 2004). Nicotine-induced LTD was not blocked by the dopamine D1 receptor antagonist SCH23390 (0.5 $\mu \mathrm{MM})$ (aCSF vs SCH23390 + nicotine: $F_{(1,23)}=$ $80, p<0.001)$ but significantly inhibited by the dopamine D2 receptor antagonist sulpiride $(5 \mu \mathrm{M})$ (nicotine vs sulpiride + nicotine: $F_{(1,30)}=24, p<0.001$ ) (Fig. $6 A$ ). Similarly, PPR was only enhanced by nicotine in SCH23390-pretreated slices, and not in slices pretreated with sulpiride $\left(\mathrm{SCH} 23390: t_{(11)}=2.39\right.$, $p=0.036$; sulpiride: $t_{(17)}=0.68, p>0.05$ ) (Fig. $6 B$ ). Sulpiride also prevented nicotine-induced decrease in sEPSC frequency (sEPSC frequency: $t_{(7)}=1.56, p>0.05$; EEPSC amplitude: $t_{(7)}=$ $1.30, p>0.05$ ) (Fig. 6C). Sulpiride did not modulate PS amplitude by itself $\left(F_{(1,18)}=2.19, p>0.05\right)$, indicating that dopamine D2 receptors are not tonically activated in these field potential recordings (data not shown). Furthermore, the dopamine D2 receptor agonist quinpirole suppressed sEPSC frequency (frequency: $t_{(5)}=5.36, p=0.003$; amplitude: $t_{(5)}=0.45, p>0.05$ ) (Fig. $6 E)$ and PS amplitude $\left(F_{(1,44)}=9.60, p<0.01\right)$, and occluded the decrease in PS amplitude induced by $1 \mu \mathrm{M}$ nicotine (nicotine vs quinpirole + nicotine: $F_{(1,28)}=16, p<0.001$; PPR: $\left.t_{(7)}=1.27, p>0.05\right)$ (Fig. 6D).
Previous studies based on ex vivo voltammetry suggest that nicotinic modulation of dopaminergic neurotransmission is highly regulated by the cholinergic tone (Exley and Cragg, 2008; Threlfell et al., 2010). In the last set of experiments, slices were thus pretreated with the mAChR agonist Oxo $(10 \mu \mathrm{M})$ or the wide-spectrum $\mathrm{mAChR}$ antagonist scopolamine $(10 \mu \mathrm{M})$. Activation of mAChRs significantly reduced sEPSC frequency, suggesting that $\mathrm{mAChR}$ activation decreases the frequency of glutamatergic inputs onto MSNs (frequency: $t_{(7)}=8.17, p<$ 0.001; amplitude: $t_{(7)}=0.81, p>0.05$ ) (Fig. 6I). Oxo furthermore suppressed PS amplitude and increased $\operatorname{PPR}\left(F_{(1,25)}=94\right.$, $p<0.001$; PPR: $t_{(16)}=5.11, p<0.001$ ) (Fig. $\left.6 F, G\right)$. Although $\mathrm{mAChRs} \mathrm{exert} \mathrm{a} \mathrm{strong} \mathrm{inhibitory} \mathrm{control} \mathrm{over} \mathrm{L-type} \mathrm{calcium}$ channels (Howe and Surmeier, 1995), synaptic depression induced by Oxo was not sensitive to the L-type calcium channel blocker nifedipine $(10 \mu \mathrm{M})\left(F_{(1,17)}=2.07, p>0.05\right.$; Fig. $\left.6 F\right)$. It was furthermore not modulated by the $\mathrm{GABA}_{\mathrm{A}}$ receptor antagonist bicuculline $(20 \mu \mathrm{M})\left(F_{(1,24)}=2.57, p>0.05\right.$; Fig. $\left.6 F\right)$. Inhibition of $\mathrm{mAChRs}$ did not significantly alter striatal neurotransmission $\left(F_{(1,39)}=0.02, p>0.05 ; \operatorname{PPR} t_{(23)}=1.94, p>\right.$ 0.05) (Fig. 6F, G).

Pretreatment with mAChR-modulating substances significantly inhibited nicotine-induced LTD (Oxo: nicotine vs nicotine + Oxo: $F_{(1,39)}=5.72, p=0.022$; aCSF vs nicotine + Oxo: $F_{(1,37)}=2.91, p>0.05$; scopolamine: nicotine vs nicotine + scopolamine: $F_{(1,48)}=13.6, p<0.001$; aCSF vs nicotine + scopolamine: $F_{(1,51)}=3.40, p>0.05$ ) (Fig. $6 \mathrm{~J}$ ). Nicotine furthermore did not increase PPR in slices pretreated with either Oxo or scopolamine (Oxo + nicotine: $t_{(17)}=1.11, p>0.05$; scopolamine + nicotine: $t_{(18)}=0.90, p>0.05$; aCSF + nicotine: $t_{(19)}=$ $4.20, p<0.001$ ) (Fig. $6 \mathrm{~K}$ ). In addition, simultaneous activation of $\mathrm{mAChRs}$ and $\mathrm{nAChRs}$ did not potentiate the decrease in PS amplitude mediated by Oxo alone (Oxo vs Oxo + nicotine: $F_{(1,25)}=$ 0.87, $p>0.05$ ) (Fig. 6F). 

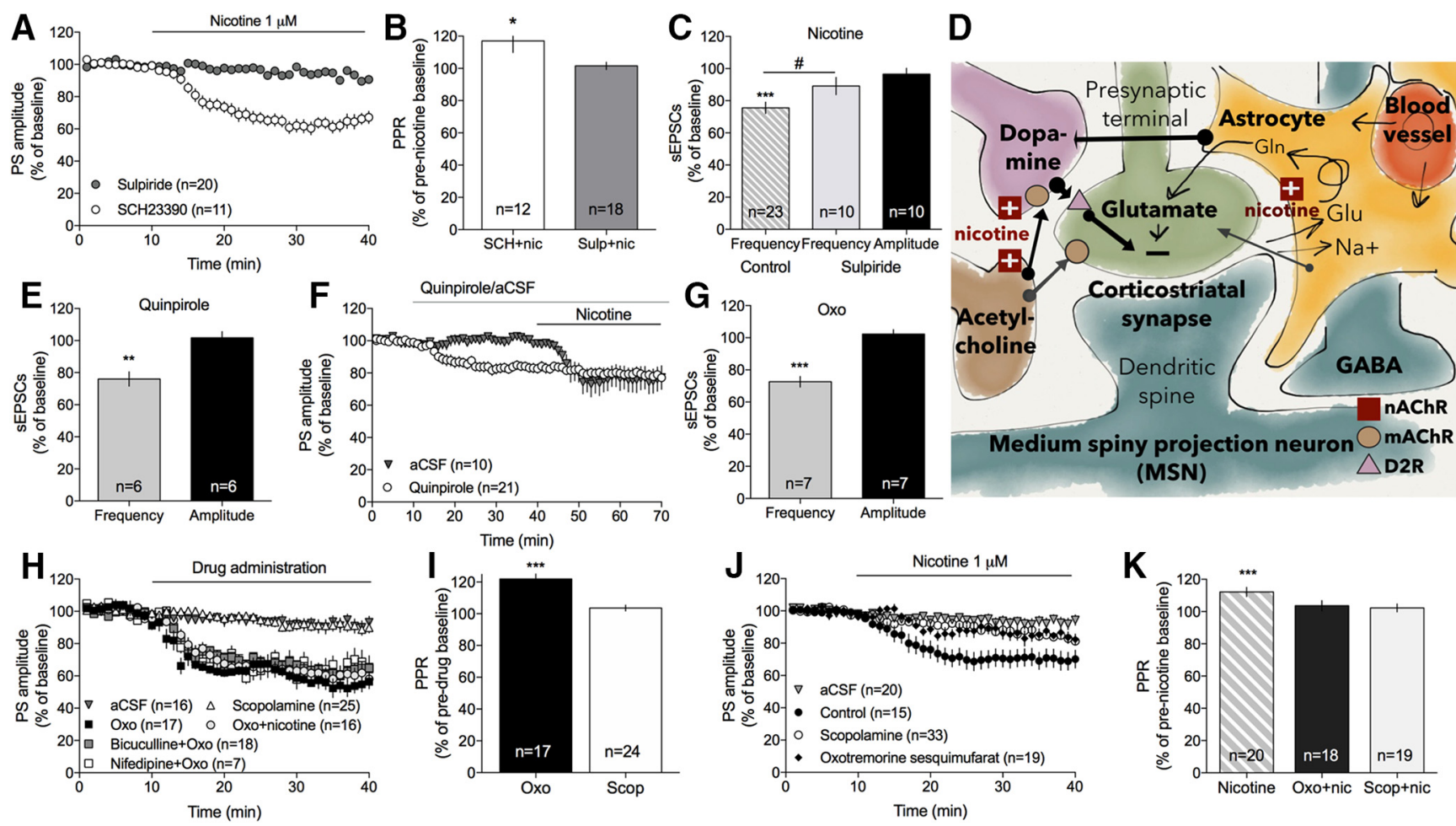

Figure 6. Nicotine-induced LTD is mediated through dopamine D2 receptor signaling. $\boldsymbol{A}, \boldsymbol{B}$, Nicotine-induced LTD and the concomitant increase in PPR were independent on dopamine D1 receptors but blocked by the dopamine D2 receptor antagonist sulpiride. C, Sulpiride also prevented nicotine-induced suppression of sEPSC frequency. D, Quinpirole suppressed PS amplitude and occluded the depressant effect displayed by nicotine. $\boldsymbol{E}$, Administration of quinpirole furthermore suppressed sEPSC frequency, but not amplitude. $\boldsymbol{F}, \boldsymbol{G}$, Activation of mAChRs reduced PS amplitude and increased PPR, whereas inhibition of mAChRs had no significant effect. Depression induced by 0 xo was not potentiated by nicotine and was not altered in slices pretreated with the $L$-type calcium channel inhibitor nifedipine, or the $\mathrm{GABA}_{\mathrm{A}}$ receptor antagonist bicuculline. $\boldsymbol{H}$, Schematic drawing showing a putative mechanism of action, where nicotine acts on $\mathrm{nAChRs}$ on dopaminergic terminals, cholinergic interneurons, and possibly astrocytes. nAChR activation may collectively facilitate dopamine release and induce depression via activation of dopamine D2 receptors that could be located on glutamatergic terminals. $\boldsymbol{I}$, Ten minutes of bath perfusion of $0 x$ reduced sEPSC frequency but had no significant effect on amplitude. $\boldsymbol{J}, \boldsymbol{K}$, Both activation and inhibition of $\mathrm{mAChRs}$ reduced nicotine-induced suppression of PS amplitude and prevented the nicotine-induced increase in PPR. Data are mean \pm SEM. $n=$ number of recordings/cells, taken from rats from at least three different litters. ${ }^{*} p<0.05$, significant compared with baseline. ${ }^{* *} p<0.01$, significant compared with baseline. ${ }^{* * *} p<0.001$, significant compared with baseline. ${ }^{\#} p<0.05$, significant compared with nicotine-treated control.

\section{Discussion}

The data presented here suggest that nicotine reduces the frequency of excitatory inputs to MSNs, resulting in a decrease in PS amplitude that is sustained during drug washout. Considering the inhibitory tone displayed by MSNs on dopaminergic cell bodies and terminals, reduced striatal output may play a role in nicotine-induced behavioral sensitization (Bamford et al., 2008; Ryu et al., 2017) but could also contribute to long-lasting neuroadaptations underlying compulsive drug-seeking habits (Yin et al., 2004; Vanderschuren et al., 2005; Adermark et al., 2016; Everitt and Robbins, 2016).

Decreased neurotransmission in the DLS following nicotine exposure is in line with a recent study showing reduced striatal glutamate levels in vivo following nicotine administration in naive animals (Ryu et al., 2017), and partially supported by the finding that in vivo administration of nicotine produces a longlasting increase in striatal PPR (Abburi et al., 2016). Nicotineinduced LTD does not appear to be connected to changes in MSN excitability but linked to a reduction in the frequency of excitatory inputs. Nicotine-induced LTD requires activation of either $\alpha 4 \beta 2$ - or $\alpha 7$-containing nAChRs and involves dopamine $\mathrm{D} 2$ receptor signaling. In addition, nicotine-induced LTD is modulated by mAChRs, which in part supports previous studies indicating a complex cooperative interaction between cholinergic interneurons and dopaminergic neurotransmission in the striatum (Rice and Cragg, 2004; Exley and Cragg, 2008; Mamaligas et al., 2016).

The depression induced by nicotine on sEPSC frequency and PS amplitude sustained in slices pretreated with the broadspectrum inhibitor mecamylamine, which is partially in line with other studies showing that a combination of mecamylamine and MLA is required to block the effects by nicotine (Lecca et al., 2000; Zanetti et al., 2006). This finding is most likely connected to mecamylamine's low affinity for $\alpha 7$-containing nAChRs (Briggs and McKenna, 1996; Frazier et al., 1998; Papke et al., 2001). $\alpha 7$ specific agonists have previously been shown to increase dopamine release (Campos et al., 2006; Huang et al., 2014), whereas antagonists attenuate nicotine-induced dopamine release (Lecca et al., 2000). Dopamine release has in these studies been linked to activation of $\alpha 7$-containing nAChRs on glutamatergic terminals, thereby indirectly stimulating dopamine release. These theories, however, are not fully supported by our data, which showed no trend toward an increase in sEPSC frequency during the initial minutes of drug wash on. In addition, the $\alpha 7$-specific agonists PNU 282987 also depressed PS amplitude, indicating that $\alpha 7$ nAChRs might affect dopamine release through additional mechanisms.

Agonists targeting $\alpha 7$ - or $\alpha 4 \beta 2$-containing nAChRs mimicked the effect by nicotine, but neither MLA nor $\mathrm{DH} \beta \mathrm{E}$ was sufficient to block nicotine-induced depression alone. Impor- 
tantly, MLA blocked the decrease in PS amplitude induced by PNU 282987, whereas the effect displayed by a low concentration of 3-bromocytisine was prevented by mecamylamine. These compounds thus appear to act selectively on $\alpha 7$ - and $\alpha 4 \beta 2$ containing nAChRs. Somewhat surprisingly, despite acting on different receptor subtypes, there was no additive effect when coactivating these nAChR subtypes. Astrocytes, which have been implicated as important regulators of neuronal function, may express both $\alpha 4 \beta 2$ - and $\alpha 7$-containing nAChRs (Delbro et al., 2009; Grybko et al., 2010; Adermark and Bowers, 2016) (Fig. $6 \mathrm{H}$ ). Astrocytes are hyperpolarized by agonists targeting nAChRs and mAChRs (Hösli et al., 1988), and nicotine has been reported to modulate the characteristics of both glial glutamate transporters and glutamine synthetase activity in cultured astrocytes (Lim and Kim, 2003). Importantly, we have previously shown that astrocytes regulate ethanol-induced dopamine release in the nucleus accumbens (Adermark et al., 2011c), and astrocytes may thus theoretically contribute to nicotine-induced modulation of striatal neurotransmission by affecting both glutamatergic and dopaminergic signaling (Fig. $6 H$ ). However, it remains to be determined whether functional $\mathrm{nAChRs}$ are expressed also on striatal astrocytes.

Cholinergic interneurons may also express a combination of $\alpha 4 \beta 2$ - and $\alpha 7$-containing $\mathrm{nAChR}$, and possibly even functional $\alpha 7 \beta 2$ nAChRs (Azam et al., 2003). Considering that $\alpha 7 \beta 2$ nAChRs appear to have a slightly different pharmacological profile (Wu et al., 2016; Nielsen et al., 2018), this might explain the need for combined administration of mecamylamine and MLA to block nicotine-induced LTD. A role for cholinergic interneurons in regulating nicotine-induced LTD is supported by the finding that scopolamine inhibited LTD and is in line with a previous study showing that nicotine-induced amino acid release in the striatum is blocked by atropine (Toth et al., 1993). Nicotine-induced LTD could thus be linked to activation of $\alpha 7 \beta 2$ nAChRs on cholinergic interneurons, leading to increased $\mathrm{mAChR}$ activation and reduced glutamate release (Fig. 6). It should be noted, however, that even though nicotine may increase cholinergic synaptic transmission (McGehee et al., 1995), reduced cholinergic firing frequency has also been reported in striatal slices after nicotine exposure (Storey et al., 2016). In addition, mAChRs may directly regulate dopamine transmission. Elevated levels of acetylcholine disrupt normal dopamine D2 receptor functioning and can even reverse the polarity of these receptors (Scarduzio et al., 2017). Scopolamine has in turn been reported to modulate dopamine release (Miller and Blaha, 2004; Volz et al., 2008) and may reduce the affinity of dopamine D2 receptors (Dewey et al., 1993; Tsukada et al., 2000). mAChRs may thus act by disrupting nicotine-induced dopamine release.

The data presented here support a role for dopamine D2 receptor signaling in regulating nicotine-induced LTD, although dopamine D1 receptor activation is not required. This finding is partially in line with previous studies, showing that lower levels of nicotine $(1 \mu \mathrm{M})$ activate dopamine D2 receptor signaling, whereas higher concentrations $(100 \mu \mathrm{M})$ are required to activate dopamine D1 receptor signaling (Hamada et al., 2004). Nicotine could stimulate dopamine release through activation of nAChRs on dopaminergic terminals, but also indirectly via activation of cholinergic interneurons and astrocytes (Fig. 6H). Nicotine could then depress striatal neurotransmission by indirectly activating dopamine D2 receptors on glutamatergic afferents. This theory is also partially supported by the finding that the dopamine D2 receptor agonist quinpirole suppressed sEPSC frequency and occluded nicotine-induced LTD.
Outlining the role of sulpiride and quinpirole in regulating nicotine-induced LTD is complicated by the fact that dopamine D2-like receptors are expressed on the majority of striatal neurons (Clarke and Adermark, 2015) and may also be expressed by astrocytes (Jennings et al., 2017). Even though dopamine D2 receptor expressing MSNs may play a role in regulating nicotineinduced LTD, current-clamp recordings do not support their involvement. In addition, sEPSC amplitude was not depressed, whereas sEPSC frequency was reduced in more or less all cells tested. It is thus unlikely that there is a differential modulation by nicotine that depends on MSN subtype.

It should be noted that acetylcholine, dopamine, and Oxo have all been shown to reduce glutamate uptake and glutamatergic activity in striatal preparations (Mitchell and Doggett, 1980; Rowlands and Roberts, 1980; Nieoullon et al., 1982; Kerkerian and Nieoullon, 1983), and might thus act by simply occluding the effect by nicotine. In addition, there is a potent crosstalk between G-protein-coupled receptors and ligand-gated ion channels in dopaminergic nerve terminals, where dopamine D2 receptors have been shown to modulate the efficacy of nAChRs (Quarta et al., 2007). More studies are thus required to fully depict the signaling pathways that mediate nicotine-induced LTD. Last, it should be noted that both dopaminergic terminals as well as cholinergic interneurons have been reported to release glutamate (Higley et al., 2011). It is thus possible that the decrease in excitatory inputs is not solely connected to corticostriatal synapses.

nAChRs may be localized both presynaptically and postsynaptically, as well as extrasynaptically, allowing nicotine to modulate neurotransmission in a multifaceted manner (Grenhoff et al., 1986; Marshall et al., 1997; Wonnacott, 1997; Gotti and Clementi, 2004; Subramaniyan and Dani, 2015). Based on our pharmacological studies, nicotine influences several neurotransmitter systems, thereby modulating striatal microcircuits in a way that leads to a long-lasting depression of striatal PS amplitude and sEPSC frequency. Even though nicotine predominately may act via $\mathrm{nAChRs}$ on dopaminergic terminals, there appear to be several players involved. Putatively, nicotine-induced modulation of both cholinergic interneurons and astrocytes may strengthen the direct effect by nicotine on dopaminergic terminals, resulting in a decreased striatal transmission via dopamine $\mathrm{D} 2$ receptor activation (Fig. 6H). However, the exact signaling pathways recruited during nicotine exposure may be impossible to depict in striatal brain slices where neurons are not uniformly oriented. It is also possible that current knowledge regarding the expression of nAChR subtypes on striatal cell populations will be refined. Independently of mechanism of action, the data presented here suggest that nicotine administration produces a long-lasting suppression of the frequency of glutamatergic inputs onto MSNs and depresses PS amplitude. These changes in neurotransmission could play a role in behavioral sensitization to nicotine but might also produce neuroadaptations that may be important for the addictive properties of nicotine (Adermark et al., 2016; Morud et al., 2018).

\section{References}

Abburi C, Wolfman SL, Metz RA, Kamber R, McGehee DS, McDaid J (2016) Tolerance to ethanol or nicotine results in increased ethanol selfadministration and long-term depression in the dorsolateral striatum. eNeuro 3:ENEURO.0112-15.2016. CrossRef Medline

Adermark L (2011) Modulation of endocannabinoid-mediated long-lasting disinhibition of striatal output by cholinergic interneurons. Neuropharmacology 61:1314-1320. CrossRef Medline

Adermark L, Bowers MS (2016) Disentangling the role of astrocytes in alcohol use disorder. Alcohol Clin Exp Res 40:1802-1816. CrossRef Medline 
Adermark L, Lovinger DM (2008) Electrophysiological properties and gap junction coupling of striatal astrocytes. Neurochem Int 52:1365-1372. CrossRef Medline

Adermark L, Lovinger DM (2009) Frequency-dependent inversion of net striatal output by endocannabinoid-dependent plasticity at different synaptic inputs. J Neurosci 29:1375-1380. CrossRef Medline

Adermark L, Clarke RB, Ericson M, Söderpalm B (2011a) Subregionspecific modulation of excitatory input and dopaminergic output in the striatum by tonically activated glycine and GABA(A) receptors. Front Syst Neurosci 5:85. CrossRef Medline

Adermark L, Clarke RB, Söderpalm B, Ericson M (2011b) Ethanol-induced modulation of synaptic output from the dorsolateral striatum in rat is regulated by cholinergic interneurons. Neurochem Int 58:693-699. CrossRef Medline

Adermark L, Clarke RB, Olsson T, Hansson E, Söderpalm B, Ericson M (2011c) Implications for glycine receptors and astrocytes in ethanolinduced elevation of dopamine levels in the nucleus accumbens. Addict Biol 16:43-54. CrossRef Medline

Adermark L, Morud J, Lotfi A, Danielsson K, Ulenius L, Söderpalm B, Ericson M (2016) Temporal rewiring of striatal circuits initiated by nicotine. Neuropsychopharmacology 41:3051-3059. CrossRef Medline

Adermark L, Morud J, Lotfi A, Ericson M, Söderpalm B (2018) Acute and chronic modulation of striatal endocannabinoid-mediated plasticity by nicotine. Addict Biol. Advance online publication. Retrieved Jan. 2, 2018. CrossRef Medline

Azam L, Winzer-Serhan U, Leslie FM (2003) Co-expression of alpha7 and beta2 nicotinic acetylcholine receptor subunit mRNAs within rat brain cholinergic neurons. Neuroscience 119:965-977. CrossRef Medline

Bamford NS, Zhang H, Joyce JA, Scarlis CA, Hanan W, Wu NP, André VM, Cohen R, Cepeda C, Levine MS, Harleton E, Sulzer D (2008) Repeated exposure to methamphetamine causes long-lasting presynaptic corticostriatal depression that is renormalized with drug readministration. Neuron 58:89-103. CrossRef Medline

Benwell ME, Balfour DJ (1992) The effects of acute and repeated nicotine treatment on nucleus accumbens dopamine and locomotor activity. $\mathrm{Br} \mathrm{J}$ Pharmacol 105:849-856. CrossRef Medline

Briggs CA, McKenna DG (1996) Effect of MK-801 at the human alpha 7 nicotinic acetylcholine receptor. Neuropharmacology 35:407-414. CrossRef Medline

Campos F, Durán R, Vidal L, Faro LR, Alfonso M (2006) In vivo effects of the anatoxin-a on striatal dopamine release. Neurochem Res 31:491-501. CrossRef Medline

Clarke R, Adermark L (2015) Dopaminergic regulation of striatal interneurons in reward and addiction: focus on alcohol. Neural Plast 2015:814567. CrossRef Medline

Clarke RB, Adermark L (2010) Acute ethanol treatment prevents endocannabinoid-mediated long-lasting disinhibition of striatal output. Neuropharmacology 58:799-805. CrossRef Medline

Corrigall WA (1999) Nicotine self-administration in animals as a dependence model. Nicotine Tob Res 1:11-20. CrossRef Medline

Delbro D, Westerlund A, Björklund U, Hansson E (2009) In inflammatory reactive astrocytes co-cultured with brain endothelial cells nicotineevoked $\mathrm{Ca}(2+)$ transients are attenuated due to interleukin-1beta release and rearrangement of actin filaments. Neuroscience 159:770-779. CrossRef Medline

Dewey SL, Smith GS, Logan J, Brodie JD, Simkowitz P, MacGregor RR, Fowler JS, Volkow ND, Wolf AP (1993) Effects of central cholinergic blockade on striatal dopamine release measured with positron emission tomography in normal human subjects. Proc Natl Acad Sci U S A 90: 11816-11820. CrossRef Medline

Di Chiara G (2000) Role of dopamine in the behavioural actions of nicotine related to addiction. Eur J Pharmacol 393:295-314. CrossRef Medline

Dorris DM, Cao J, Willett JA, Hauser CA, Meitzen J (2015) Intrinsic excitability varies by sex in prepubertal striatal medium spiny neurons. J Neurophysiol 113:720-729. CrossRef Medline

English DF, Ibanez-Sandoval O, Stark E, Tecuapetla F, Buzsáki G, Deisseroth K, Tepper JM, Koós T (2011) GABAergic circuits mediate the reinforcement-related signals of striatal cholinergic interneurons. Nat Neurosci 15:123-130. CrossRef Medline

Everitt BJ, Robbins TW (2016) Drug addiction: updating actions to habits to compulsions ten years on. Annu Rev Psychol 67:23-50. CrossRef Medline
Exley R, Cragg SJ (2008) Presynaptic nicotinic receptors: a dynamic and diverse cholinergic filter of striatal dopamine neurotransmission. $\mathrm{Br} \mathrm{J}$ Pharmacol 153 [Suppl. 1]:S283-S297. CrossRef Medline

Faust TW, Assous M, Tepper JM, Koós T (2016) Neostriatal GABAergic interneurons mediate cholinergic inhibition of spiny projection neurons. J Neurosci 36:9505-9511. CrossRef Medline

Frazier CJ, Rollins YD, Breese CR, Leonard S, Freedman R, Dunwiddie TV (1998) Acetylcholine activates an alpha-bungarotoxin-sensitive nicotinic current in rat hippocampal interneurons, but not pyramidal cells. J Neurosci 18:1187-1195. CrossRef Medline

Gerdeman GL, Partridge JG, Lupica CR, Lovinger DM (2003) It could be habit forming: drugs of abuse and striatal synaptic plasticity. Trends Neurosci 26:184-192. CrossRef Medline

Gotti C, Clementi F (2004) Neuronal nicotinic receptors: from structure to pathology. Prog Neurobiol 74:363-396. CrossRef Medline

Goutier W, Lowry JP, McCreary AC, O'Connor JJ (2016) Frequencydependent modulation of dopamine release by nicotine and dopamine D1 receptor ligands: an in vitro fast cyclic voltammetry study in rat striatum. Neurochem Res 41:945-950. CrossRef Medline

Grenhoff J, Aston-Jones G, Svensson TH (1986) Nicotinic effects on the firing pattern of midbrain dopamine neurons. Acta Physiol Scand 128: 351-358. CrossRef Medline

Grybko M, Sharma G, Vijayaraghavan S (2010) Functional distribution of nicotinic receptors in CA3 region of the hippocampus. J Mol Neurosci 40:114-120. CrossRef Medline

Hamada M, Higashi H, Nairn AC, Greengard P, Nishi A (2004) Differential regulation of dopamine D1 and D2 signaling by nicotine in neostriatal neurons. J Neurochem 90:1094-1103. CrossRef Medline

Higley MJ, Gittis AH, Oldenburg IA, Balthasar N, Seal RP, Edwards RH, Lowell BB, Kreitzer AC, Sabatini BL (2011) Cholinergic interneurons mediate fast VGluT3-dependent glutamatergic transmission in the striatum. PLoS One 6:e19155. CrossRef Medline

Hikosaka O, Sakamoto M, Usui S (1989) Functional properties of monkey caudate neurons: III. Activities related to expectation of target and reward. J Neurophysiol 61:814-832. CrossRef Medline

Hösli L, Hösli E, Della Briotta G, Quadri L, Heuss L (1988) Action of acetylcholine, muscarine, nicotine and antagonists on the membrane potential of astrocytes in cultured rat brainstem and spinal cord. Neurosci Lett 92:165-170. CrossRef Medline

Howe AR, Surmeier DJ (1995) Muscarinic receptors modulate N-, P-, and L-type $\mathrm{Ca}^{2+}$ currents in rat striatal neurons through parallel pathways. J Neurosci 15:458-469. CrossRef Medline

Howe WM, Young DA, Bekheet G, Kozak R (2016) Nicotinic receptor subtypes differentially modulate glutamate release in the dorsal medial striatum. Neurochem Int 100:30-34. CrossRef Medline

Huang M, Felix AR, Flood DG, Bhuvaneswaran C, Hilt D, Koenig G, Meltzer HY (2014) The novel alpha7 nicotinic acetylcholine receptor agonist EVP-6124 enhances dopamine, acetylcholine, and glutamate efflux in rat cortex and nucleus accumbens. Psychopharmacology 231:4541-4551. CrossRef Medline

Jennings A, Tyurikova O, Bard L, Zheng K, Semyanov A, Henneberger C, Rusakov DA (2017) Dopamine elevates and lowers astroglial $\mathrm{Ca}^{2+}$ through distinct pathways depending on local synaptic circuitry. Glia 65:447-459. CrossRef Medline

Kaiser S, Wonnacott S (2000) $\alpha$-Bungarotoxin-sensitive nicotinic receptors indirectly modulate $[(3) \mathrm{H}]$ dopamine release in rat striatal slices via glutamate release. Mol Pharmacol 58:312-318. CrossRef Medline

Kandel D, Chen K, Warner LA, Kessler RC, Grant B (1997) Prevalence and demographic correlates of symptoms of last year dependence on alcohol, nicotine, marijuana and cocaine in the U.S. population. Drug Alcohol Depend 44:11-29. CrossRef Medline

Kerkerian L, Nieoullon A (1983) Effects of acetylcholine on sodiumdependent high-affinity glutamate transport in rat striatal homogenates. J Neurochem 40:1287-1292. CrossRef Medline

Koós T, Tepper JM (2002) Dual cholinergic control of fast-spiking interneurons in the neostriatum. J Neurosci 22:529-535. CrossRef Medline

Koós T, Tepper JM, Wilson CJ (2004) Comparison of IPSCs evoked by spiny and fast-spiking neurons in the neostriatum. J Neurosci 24:79167922. CrossRef Medline

Lecca D, Shim I, Costa E, Javaid JI (2000) Striatal application of nicotine, but not of lobeline, attenuates dopamine release in freely moving rats. Neuropharmacology 39:88-98. CrossRef Medline 
Lim DK, Kim HS (2003) Opposite modulation of glutamate uptake by nicotine in cultured astrocytes with/without cAMP treatment. Eur J Pharmacol 476:179-184. CrossRef Medline

Luo R, Janssen MJ, Partridge JG, Vicini S (2013) Direct and GABAmediated indirect effects of nicotinic ACh receptor agonists on striatal neurones. J Physiol 591:203-217. CrossRef Medline

Mamaligas AA, Cai Y, Ford CP (2016) Nicotinic and opioid receptor regulation of striatal dopamine D2-receptor mediated transmission. Sci Rep 6:37834. CrossRef Medline

Marshall DL, Redfern PH, Wonnacott S (1997) Presynaptic nicotinic modulation of dopamine release in the three ascending pathways studied by in vivo microdialysis: comparison of naive and chronic nicotine-treated rats. J Neurochem 68:1511-1519. CrossRef Medline

Mathur BN, Tanahira C, Tamamaki N, Lovinger DM (2013) Voltage drives diverse endocannabinoid signals to mediate striatal microcircuit-specific plasticity. Nat Neurosci 16:1275-1283. CrossRef Medline

McGehee DS, Heath MJ, Gelber S, Devay P, Role LW (1995) Nicotine enhancement of fast excitatory synaptic transmission in CNS by presynaptic receptors. Science 269:1692-1696. CrossRef Medline

Miller AD, Blaha CD (2004) Nigrostriatal dopamine release modulated by mesopontine muscarinic receptors. Neuroreport 15:1805-1808. CrossRef Medline

Mitchell PR, Doggett NS (1980) Modulation of striatal $\left[{ }^{3} \mathrm{H}\right]$-glutamic acid release by dopaminergic drugs. Life Sci 26:2073-2081. CrossRef Medline

Morud J, Strandberg J, Andrén A, Ericson M, Söderpalm B, Adermark L (2018) Progressive modulation of accumbal neurotransmission and anxiety-like behavior following protracted nicotine withdrawal. Neuropharmacology 128:86-95. CrossRef Medline

Nielsen BE, Minguez T, Bermudez I, Bouzat C (2018) Molecular function of the novel $\alpha 7 \beta 2$ nicotinic receptor. Cell Mol Life Sci 75:2457-2471. CrossRef Medline

Nieoullon A, Kerkerian L, Dusticier N (1982) Inhibitory effects of dopamine on high affinity glutamate uptake from rat striatum. Life Sci 30: 1165-1172. CrossRef Medline

Papke RL, Sanberg PR, Shytle RD (2001) Analysis of mecamylamine stereoisomers on human nicotinic receptor subtypes. J Pharmacol Exp Ther 297:646-656. Medline

Partridge JG, Apparsundaram S, Gerhardt GA, Ronesi J, Lovinger DM (2002) Nicotinic acetylcholine receptors interact with dopamine in induction of striatal long-term depression. J Neurosci 22:2541-2549. CrossRef Medline

Patton MH, Roberts BM, Lovinger DM, Mathur BN (2016) Ethanol disinhibits dorsolateral striatal medium spiny neurons through activation of A presynaptic delta opioid receptor. Neuropsychopharmacology 41:18311840. CrossRef Medline

Quarta D, Ciruela F, Patkar K, Borycz J, Solinas M, Lluis C, Franco R, Wise RA, Goldberg SR, Hope BT, Woods AS, Ferré S (2007) Heteromeric nicotinic acetylcholine-dopamine autoreceptor complexes modulate striatal dopamine release. Neuropsychopharmacology 32:35-42. CrossRef Medline

Quintana A, Sanz E, Wang W, Storey GP, Güler AD, Wanat MJ, Roller BA, La Torre A, Amieux PS, McKnight GS, Bamford NS, Palmiter RD (2012) Lack of GPR88 enhances medium spiny neuron activity and alters motorand cue-dependent behaviors. Nat Neurosci 15:1547-1555. CrossRef Medline

Rice ME, Cragg SJ (2004) Nicotine amplifies reward-related dopamine signals in striatum. Nat Neurosci 7:583-584. CrossRef Medline

Rowlands GF, Roberts PJ (1980) Activation of dopamine receptors inhibits calcium-dependent glutamate release from cortico-striatal terminals in vitro. Eur J Pharmacol 62:241-242. CrossRef Medline

Ryu IS, Kim J, Seo SY, Yang JH, Oh JH, Lee DK, Cho HW, Yoon SS, Seo JW, Chang S, Kim HY, Shim I, Choe ES (2017) Behavioral changes after nicotine challenge are associated with alpha7 nicotinic acetylcholine receptor-stimulated glutamate release in the rat dorsal striatum. Sci Rep 7:15009. CrossRef Medline

Scarduzio M, Zimmerman CN, Jaunarajs KL, Wang Q, Standaert DG, McMahon LL (2017) Strength of cholinergic tone dictates the polarity of dopamine D2 receptor modulation of striatal cholinergic interneuron excitability in DYT1 dystonia. Exp Neurol 295:162-175. CrossRef Medline

Siciliano CA, McIntosh JM, Jones SR, Ferris MJ (2017) alpha6beta2 subunit containing nicotinic acetylcholine receptors exert opposing actions on rapid dopamine signaling in the nucleus accumbens of rats with highversus low-response to novelty. Neuropharmacology 126:281-291. CrossRef Medline

Silberberg G, Bolam JP (2015) Local and afferent synaptic pathways in the striatal microcircuitry. Curr Opin Neurobiol 33:182-187. CrossRef Medline

Singer G, Wallace M, Hall R (1982) Effects of dopaminergic nucleus accumbens lesions on the acquisition of schedule induced self injection of nicotine in the rat. Pharmacol Biochem Behav 17:579-581. CrossRef Medline

Storey GP, Gonzalez-Fernandez G, Bamford IJ, Hur M, McKinley JW, Heimbigner L, Minasyan A, Walwyn WM, Bamford NS (2016) Nicotine modifies corticostriatal plasticity and amphetamine rewarding behaviors in mice(1,2,3). eNeuro 3:ENEURO.0095-15.2015. CrossRef Medline

Subramaniyan M, Dani JA (2015) Dopaminergic and cholinergic learning mechanisms in nicotine addiction. Ann N Y Acad Sci 1349:46-63. CrossRef Medline

Tepper JM, Koós T, Wilson CJ (2004) GABAergic microcircuits in the neostriatum. Trends Neurosci 27:662-669. CrossRef Medline

Threlfell S, Clements MA, Khodai T, Pienaar IS, Exley R, Wess J, Cragg SJ (2010) Striatal muscarinic receptors promote activity dependence of dopamine transmission via distinct receptor subtypes on cholinergic interneurons in ventral versus dorsal striatum. J Neurosci 30:3398-3408. CrossRef Medline

Toth E, Vizi ES, Lajtha A (1993) Effect of nicotine on levels of extracellular amino acids in regions of the rat brain in vivo. Neuropharmacology 32: 827-832. CrossRef Medline

Tsukada H, Harada N, Nishiyama S, Ohba H, Kakiuchi T (2000) Cholinergic neuronal modulation alters dopamine D2 receptor availability in vivo by regulating receptor affinity induced by facilitated synaptic dopamine turnover: positron emission tomography studies with microdialysis in the conscious monkey brain. J Neurosci 20:7067-7073. CrossRef Medline

Vanderschuren LJ, Di Ciano P, Everitt BJ (2005) Involvement of the dorsal striatum in cue-controlled cocaine seeking. J Neurosci 25:8665-8670. CrossRef Medline

Volkow ND, Wang GJ, Telang F, Fowler JS, Logan J, Childress AR, Jayne M, Ma Y, Wong C (2006) Cocaine cues and dopamine in dorsal striatum: mechanism of craving in cocaine addiction. J Neurosci 26:6583-6588. CrossRef Medline

Volz TJ, Farnsworth SJ, Rowley SD, Hanson GR, Fleckenstein AE (2008) Methylphenidate-induced increases in vesicular dopamine sequestration and dopamine release in the striatum: the role of muscarinic and dopamine D2 receptors. J Pharmacol Exp Ther 327:161-167. CrossRef Medline

Witten IB, Lin SC, Brodsky M, Prakash R, Diester I, Anikeeva P, Gradinaru V, Ramakrishnan C, Deisseroth K (2010) Cholinergic interneurons control local circuit activity and cocaine conditioning. Science 330:16771681. CrossRef Medline

Wonnacott S (1997) Presynaptic nicotinic ACh receptors. Trends Neurosci 20:92-98. CrossRef Medline

Wu J, Liu Q, Tang P, Mikkelsen JD, Shen J, Whiteaker P, Yakel JL (2016) Heteromeric alpha7beta2 nicotinic acetylcholine receptors in the brain. Trends Pharmacol Sci 37:562-574. CrossRef Medline

Xu M, Kobets A, Du JC, Lennington J, Li L, Banasr M, Duman RS, Vaccarino FM, DiLeone RJ, Pittenger C (2015) Targeted ablation of cholinergic interneurons in the dorsolateral striatum produces behavioral manifestations of Tourette syndrome. Proc Natl Acad Sci U S A 112:893-898. CrossRef Medline

Yin HH, Knowlton BJ, Balleine BW (2004) Lesions of dorsolateral striatum preserve outcome expectancy but disrupt habit formation in instrumental learning. Eur J Neurosci 19:181-189. CrossRef Medline

Yin HH, Ostlund SB, Balleine BW (2008) Reward-guided learning beyond dopamine in the nucleus accumbens: the integrative functions of corticobasal ganglia networks. Eur J Neurosci 28:1437-1448. CrossRef Medline

Zanetti L, de Kerchove D'Exaerde A, Zanardi A, Changeux JP, Picciotto MR, Zoli M (2006) Inhibition of both alpha7* and beta2* nicotinic acetylcholine receptors is necessary to prevent development of sensitization to cocaine-elicited increases in extracellular dopamine levels in the ventral striatum. Psychopharmacology 187:181-188. CrossRef Medline

Zhou FM, Wilson CJ, Dani JA (2002) Cholinergic interneuron characteristics and nicotinic properties in the striatum. J Neurobiol 53:590-605. CrossRef Medline 